\title{
Mechanical Dewatering and Water Leaching Pretreatment of Fresh Banagrass, Guinea Grass, Energy Cane, and Sugar Cane: Characterization of Fuel Properties and Byproduct Streams
}

\author{
Hong Cui*, Scott Q Turn, Thai Tran, and Daniel Rogers \\ Hawaii Natural Energy Institute, University of Hawaii at Manoa \\ 1680 East-West Rd, POST 109, Honolulu, HI 96822
}

\begin{abstract}
:
Tropical biomass feedstock candidates, banagrass (Pennisetum purpureum x Pennisetum glaucum), guinea grass (Panicum maximum), energy cane (Saccharum spontaneum), and sugar cane (Saccharum officinarum L.) (as reference) were harvested and processed using pressing and leaching techniques to improve fuel properties for thermochemical conversion. Test results are reported that summarize the impacts of treatment methods on fuel properties and provide detailed data on mass and element partitioning between process streams to inform system design. The processed fuels had lower ash contents, improved heating values, higher ash deformation temperatures, and higher volatile matter to fixed carbon ratios than the parent materials. The liquid streams generated by the process were characterized for chemical oxygen demand, sugar content, total solids, total suspended solids, and major and trace elements. At least $20 \%$ of the initial fuel dry matter was partitioned to the byproduct liquid streams as total solids under the combined influences of leaching and mechanical processing. Analytical results support the land application of liquids as a nutrient recycling option. Element partitioning between solid and liquid process streams was determined and material and element mass balances were performed. Chemical equilibrium calculations based on the elemental composition of the parent materials and processed fuels and steam gasification conditions predicted substantial reductions in concentrations of $\mathrm{K}, \mathrm{Cl}, \mathrm{S}, \mathrm{Na}$, and $\mathrm{Mg}$ in the product gas.
\end{abstract}

Keywords: fresh biomass; fuel processing; fuel properties; waste liquids analysis; inorganic impurity elements; trace elements; thermochemical conversion

Corresponding author. Tel: +1 808956 5397; fax: +1 8089562344

E-mail address: hongcui@ hawaii.edu (Hong Cui). 


\section{INTRODUCTION}

Using biomass to produce fuels, power, and chemicals in biorefinery applications is of increasing importance in addressing issues of global warming and sustainability. Thermochemical conversion systems will play an important role in large scale implementation of biomass based systems either as a primary platform using biomass directly or as a secondary conversion system to handle residue streams from biochemical processes. Fuel properties of biomass vary depending upon their source and will dictate the degree of processing required for a targeted thermochemical conversion application.

In a typical plant, minerals or organo-minerals that support growth, development, and health, may include $\mathrm{K}, \mathrm{P}, \mathrm{Ca}, \mathrm{Mg}, \mathrm{S}, \mathrm{Na}, \mathrm{Si}, \mathrm{Fe}, \mathrm{Ti}, \mathrm{Al}$, and $\mathrm{Cl}$ as major elements, and $\mathrm{Be}, \mathrm{Mn}, \mathrm{Cd}, \mathrm{Cu}, \mathrm{Zn}, \mathrm{Pb}$, etc. as trace elements [1]. These elements, extracted by plants from soils, applied fertilizers, or persistent anthropogenic chemical compounds in the environment, may contribute to operating difficulties at thermochemical biomass conversion operating temperatures or impact downstream materials and equipment [2]. Alkali metals ( $\mathrm{Na}$ and $\mathrm{K}$ ), for example, which typically have higher concentration in biomass plants compared with coal [3], can react with other elements ( $\mathrm{S}, \mathrm{Cl}, \mathrm{Si}, \mathrm{Ca}, \mathrm{Mg}$, etc.) at elevated temperatures to cause ash deposition, fouling, or corrosion, and agglomeration in fluidized beds. Vapor phase alkali metals are limited to 50 to $100 \mathrm{ppb}$ in fuel gas [4, 5] to protect gas turbines [6, 7]. A stricter tolerance, $<10 \mathrm{ppb}$, is cited for both alkali metals and hydrogen chloride $(\mathrm{HCl})$ in syngas supply for Fischer-Tropsch synthesis [8]. In addition, trace elements present in fuel gas have adverse effects on catalysts in fuel/chemical synthesis and solid oxide fuel cells (SOFC) [2]. Therefore, removing troublesome elements from biomass fuel should be given priority for fuel improvement [9].

Mechanical dewatering followed by water washing or leaching has been applied in lab scale tests for fuel improvement on banagrass (Pennisetum purpureum $\mathrm{x}$ Pennisetum glaucum)[9]. The process was demonstrated to be effective as a way to reduce ash content by removing a high percentage of water soluble minerals from solid parent material into liquid byproducts. The processed banagrass fuel has characteristics similar to sugarcane (Saccharum officinarum L.) bagasse, a common boiler fuel in sugar factories. Water washing/rinsing is also effective in processing other biomass crops or wastes, such as wheat and rice straw [10-14], corn stover [13, 14], switch grass [13], wood waste [12, 14], and olive-oil processing residue [15]. The processed fuels are reported to have better performance than the parent materials and to avoid rapid and undesirable ash deposition and/or agglomeration problems in benchscale and lab-scale fluidized bed gasifiers and combustors [10, 15-18]. The process generates some volume of liquid containing water soluble ions and organic matter (juice or pulp), which requires evaluation prior to recovery or disposal. Yu, et al.'s [13] analyses of leachate samples found that inorganic and organic materials removed by the leaching process were as high as $4.6 \%$ and $15.4 \%$ of dry matter, respectively, and that biomass type played a role. Jenkins [19] studied rice straw leachate treatment by reverse osmosis and obtained a clear advantage for water recycling and brine reduction in disposal. 
All experimental tests in this paper used freshly harvested material from four types of tropical herbaceous plants, namely banagrass (Pennisetum purpureum x Pennisetum glaucum), guinea grass (Panicum maximum), and energy cane (Sacharum spontaneum), as well as sugarcane (Saccharum officinarum L.) as reference. A screw press was used to mechanically dewater the samples in a continuous mode. The fuel properties of the processed solids were evaluated, including proximate analysis, ultimate analysis, ash composition, and trace element analysis. Liquid byproducts were selectively analyzed for chemical oxygen demand (COD), sugar content, mineral nutrients, and trace elements to identify potential beneficial use options, suitability for direct land application, or treatment requirements. Element partitioning between solid and liquid process streams was determined and mass balances of material and element were performed. Based on the properties of processed fuel, chemical equilibrium calculation was conducted for steam gasification conditions to predict the concentration of gaseous elements of concern in gas stream.

\section{MATERIALS AND METHODS}

Materials and methods for the fuel processing experiments are described below.

\subsection{Materials}

Four types of tropical herbaceous plants, in total eight material lots, were used in the tests. The material lots included four banagrass, one guinea grass, two energy cane, and one sugarcane. Lot IDs and harvest information are presented in Table 1.

\subsection{Fuel processing}

As shown schematically in Fig. 1, freshly harvested plants were subjected to the following sequence of processing steps; shredding, initial juice removal, water rinsing, secondary juice/water removal, and drying.

Freshly harvested plant samples were reduced to $\sim 6 \mathrm{~mm}$ particles by a shredder (Model VCS-8, Vincent Corporation, Tampa, FL, USA), and then expressed using a compact screw press (Model CP-4, Vincent Corporation, Tampa, FL, USA) for initial juice removal. The shredded parent material (S0) was pressed to generate a solid fuel sample (S1) and initial plant juice (L1). The S1 samples were loaded in a basket with walls made from 100 mesh screen and immersed in a barrel filled with enough tap water to submerge all of the material. Tap water was used to leach the solid (S1) at a water to solid mass ratio of 6.0. Leaching and draining free leachate (L2) from the material were completed in $\sim 5$ min. Previous work found that longer contact times did not result in improved leaching efficiency[9]. Once drained of free leachate, the leached solid material (S2) was subjected to a second dewatering treatment with the screw press to produce the final solid fuel (S3) and a liquid stream (L3).

The screw press operated at a constant rpm and was equipped with a pneumatically loaded cone that applied pressure to the screw discharge. For each step, the screw press was operated with the same pressure applied to the screw discharge for both the initial and second pressing. As illustrated in Fig. 2 , 
the pneumatic cylinder (1) pulls on a lever arm (2) that applies force to the back of the cone (3). Pressure in the pneumatic cylinder can be varied up to $550 \mathrm{kPa}$. In preliminary tests, a load cell (Model: SSM-AJ500, Interface, Arizona, USA) was placed between the cylinder piston and the lever arm to measure the force during operation. The force applied to the back of the cone was calculated using the data from the load cell and the geometry of the linkage components. Load cell measurements were made for air cylinder pressures of $69,138,207,276,345,414,483$, and $550 \mathrm{kPa}$. For the remainder of the tests, an air cylinder pressure of $207 \mathrm{kPa}$ was used.

\subsection{Sample analysis}

The solid and liquid byproduct streams generated by the screw press and water rinse were collected and sampled. Solid samples were dried at $105^{\circ} \mathrm{C}$ immediately, and liquid samples were stored in a refrigerator at $4{ }^{\circ} \mathrm{C}$ until analysis was conducted.

Both solid and liquid samples were analyzed to obtain information on elemental composition and distribution. In addition, fuel properties of solid samples were characterized using ASTM methods for ultimate $(\mathrm{C}, \mathrm{H}, \mathrm{N}, \mathrm{S}$, and $\mathrm{Cl}$ ), proximate analyses (moisture, volatile matter (VM), fixed carbon (FC), and ash content), energy content (high heating value), ash composition $\left(\mathrm{SiO}_{2}, \mathrm{Al}_{2} \mathrm{O}_{3}, \mathrm{TiO}_{2}, \mathrm{FeO}_{3}, \mathrm{CaO}, \mathrm{MgO}\right.$, $\mathrm{Na}_{2} \mathrm{O}, \mathrm{K}_{2} \mathrm{O}, \mathrm{P}_{2} \mathrm{O}_{5}, \mathrm{SO}_{3}, \mathrm{Cl}$, and $\mathrm{CO}_{2}$ ), and ash deformation temperatures in reducing and oxidizing atmospheres.

Trace elements present in the solid fuels were quantified by preparing ash samples at $600^{\circ} \mathrm{C}$, digesting the ash, and analyzing the resulting samples using an inductively coupled plasma equipped with an atomic emission spectrophotometer (ICP-AES).

Concentrations of $\mathrm{K}^{+}, \mathrm{Na}^{+}, \mathrm{Ca}^{2+},\left(\mathrm{Ca}^{2+}+\mathrm{Mg}^{2+}\right)$, and $\mathrm{Cl}^{-}$present in liquid samples were measured using ion selective electrodes (ISE) (Cole-Parmer, Vernon Hills, IL. Cat. No. 27504-26 for K ${ }^{+}$; Cat. No. 2750430 for $\mathrm{Na}^{+}$; Cat. No. 27504-06 for $\mathrm{Ca}^{2+}$, Cat. No. 27504-34 for $\left(\mathrm{Ca}^{2+}+\mathrm{Mg}^{2+}\right)$ (water hardness) and Cat. No 27504-08 for $\mathrm{Cl}^{-}$). The other metal elements including trace elements were determined by ICP-AES.

The electrical conductivity (EC) and chemical oxygen demand (COD) of selected liquid samples were measured using a conductivity meter (Model: 21800-012, Control Company, Friendswood, Texas, USA), and COD digestion vials (Hach Company product \# 2125925), respectively. Total solids (TS) and total suspended solids (TSS) in the liquids were measured using Method 2540 in Standards Methods for the Examination of Water and Wastewater (20 th Edition, 1998) [20]. Sugar analysis was conducted for selected liquid samples using an HPLC equipped with a KS-G guard column, a Shodex KS-801 column, and an evaporative light scattering detector (Alltech ELSD 2000es). The system was operated with a water mobile phase flow rate of $0.42 \mathrm{ml} / \mathrm{min}, 10 \mu \mathrm{l}$ injection volume, and column temperatures of $75{ }^{\circ} \mathrm{C}$. Standards were prepared using a carbohydrate kit (model CAR10-1KT, Sigma-Aldrich).

Soils were sampled at the Poamoho and Waimanalo sites shown in Table 1 where test material lots were acquired. In each location, 5 to 10 soil samples of $\sim 500 \mathrm{ml}$ were taken from the 0 to $15 \mathrm{~cm}$ depth of 
the soil profile. The samples were air dried, commingled, and subsampled. Subsamples were digested according to EPA Method 3050B and analyzed with IPC-AES.

\subsection{Chemical equilibrium calculation by using FACT Sage}

Following methods outlined by Turn [21], FactSage [22] software was used to calculate chemical equilibrium products using the biomass chemical composition as input and conditions typical of steam gasification: a temperature of $900{ }^{\circ} \mathrm{C}, 1$ bar pressure, and a steam to dry fuel ratio of 2:1. Results from parent biomass fuel and processed fuel were compared to explore the effects of biomass processing on the reduction of contaminants in the product gas.

\section{RESULTS AND DISCUSSION}

Results from the fuel processing tests are presented and discussed in the following sections.

\subsection{Fuel processing conditions}

Results of the preliminary test conducted to measure pressure on the exit cone of the screw press as a function of air cylinder pressure are presented in Fig. 3. Regression of the data indicates a linear relationship and the regression equation is included in the figure. In the following sections of the report, designations of P0, P138, P276, and P414, indicate the pressure setting of the screw press air cylinder while processing the Bana samples. These air cylinder settings correspond to effective exit cone pressures of $0,34,91$, and $147 \mathrm{kPa}$, respectively. A single air cylinder pressure setting of $207 \mathrm{kPa}$ (P207) corresponding to an effective cone pressure of $72 \mathrm{kPa}$ was used to process G-Bana, P-Bana, P-Bana(II), OG03, E-cane, E-cane (II), and S-cane samples.

\subsection{Fuel properties of solid fuel products}

Fuel properties of S0, S1, and S3 materials from the G-Bana, P-Bana, OG-03 and E-cane processing experiments are presented in Table 2. The four, unprocessed, S0 samples exhibited values within relatively narrow ranges. Fixed carbon (FC) and volatile matter (VM) values were within $\sim 3.5 \%$ (absolute) and $\sim 6 \%$ (absolute), respectively, of each other. OG03 had the highest ash content, 8.2\%, compared with the lowest content of $5.3 \%$ for E-cane. Sulfur (S) content ranged from 0.06 to $0.30 \%$ with E-cane at the upper end of the range. Chlorine $(\mathrm{Cl})$ content in $\mathrm{S} 0$ samples varied from 0.41 to $0.86 \%$ with $\mathrm{P}-\mathrm{Bana}$ and OG03 at the upper end of the range and E-cane at the bottom. $\mathrm{SiO}_{2}$ accounted for $\sim 54 \%$ of the ash in all $\mathrm{S} 0$ samples. $\mathrm{K}_{2} \mathrm{O}$ was the next most abundant ash component ranging from 15 to $20 \%$. $\mathrm{CaO}, \mathrm{MgO}, \mathrm{P}_{2} \mathrm{O}_{5}$, and $\mathrm{Cl}$ were all present in the ash in the range of 3 to $9 \%$. Differences in ash composition among the S0 materials produced initial ash deformation temperatures spanning 1,030 to $1,130{ }^{\circ} \mathrm{C}$ in oxidizing and reducing atmospheres.

Fuels with reduced moisture enhance process control in thermochemical conversion systems. As shown in Table 2, passing the S0 samples through the screw press reduced moisture contents of S1 samples by $8-19 \%$ (absolute). All S1 samples had moisture content in a range from 46 to $51 \%$ wet basis. 
Sugar cane bagasse at this moisture is commonly fired in steam generator units at sugar factories to produce steam and in turn, mechanical and electrical power and process heat. This moisture content is, however, too high to be used as feedstock for gasification or pyrolysis, where the feedstock is required to be $\leq 20 \%$ wet basis. Reducing moisture also aids in the prevention of microbial activity and may stabilize stored fuel. Note that S3 samples had higher moisture content than S1 samples. The S2 materials were water-saturated after the rinse process and had higher moisture contents than the unprocessed S0 samples, the inputs for S1 samples. As a result, processed S3 fuels had moisture content ranging from 52 to $57 \%$ wet basis.

Ultimate analysis results (Table 2) show little change in $\mathrm{C}$ and $\mathrm{H}$ content in the processed samples. This is not unexpected given that fuel processing was a mild physical process unlikely to change the chemical structure. Contents of element $\mathrm{N}, \mathrm{S}$, and $\mathrm{Cl}$ were reduced in $\mathrm{S} 1$ and $\mathrm{S} 3$ samples. The water leaching and screw press steps between the S1 and S3 materials was particularly effective at $\mathrm{K}$ and $\mathrm{Cl}$ removal.

The ash composition analysis in Table 2 shows that G-Bana, P-Bana, OG03, and E-cane had reduced concentrations of $\mathrm{Mg}, \mathrm{Na}, \mathrm{K}, \mathrm{P}$, and $\mathrm{Cl}$ and increased concentrations of $\mathrm{Si}$ in processed fuel samples when compared with unprocessed samples. Ash fusion temperatures were altered for treated samples. In Table 2, all S3 samples generated from G-Bana, P-Bana, OG03, and E-cane had higher ash fusion temperatures $\left(>1482{ }^{\circ} \mathrm{C}\right)$ under both reducing and oxidizing atmospheres, indicating that processing resulted in a more refractory material by removing alkali and alkaline earth elements.

The proximate analysis results indicate that both S1 and S3 samples had reduced ash contents and consequently increased high heating values (HHV). Processed materials, S1 and S3, displayed higher values of volatile matter (VM) and lower values of fixed carbon (FC) compared to the parent material (S0). The finding is supported by current and previous work for grasses [9], and also by results reported elsewhere for agricultural waste and woody materials [23, 24], i.e. sugar beet pulp, potato pulp, and green mallee tree components (wood, leaf, and bark). Fig. 4 summarizes and compares available data with

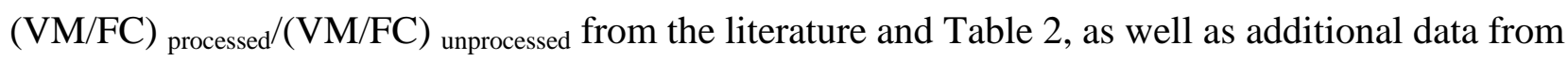
processed Bana samples (P0, P138, P276, and P414). Note that all S3 samples had higher values than the $\mathrm{S} 1$ samples in this study, but that not all data from the literature exhibited an increase in VM/FC as a result of processing. For example, olive residue and wheat straw in Arvelakis et al.'s article [15] did not show a change in VM/FC after processing, although their ash contents were obviously reduced.

Changes in VM/FC appeared to relate to changes in composition resulting from the removal of either organic or inorganic fractions due to fuel processing. Kannan and Richards [24] investigated the effects of acid washing on char yield of sugar beet pulp and potato pulp, and found acid washing caused a major reduction in the char yield, considerably greater than the reduction accounted for by the reduced ash content. Fahmi et al. [25] studying the effect of alkali metals on combustion and pyrolysis of Lolium and Festuca grasses, switch grass, and willow chips using thermogravimetric analysis (TGA), found that the pyrolysis char increased with the content of $\mathrm{K}$ and $\mathrm{Na}$ in the fuel, suggesting that metal species favor the 
char-forming reactions, possibly at the expense of reactions leading to pyrolysis oils. Similar conclusion was made in Jensen and Dam-Johansen's paper [26]. In their study, washing reduced the char yield of wheat straw from 23 to $12 \mathrm{wt} \%$ (daf), reduced gas yield and increased tar yield from 32 to $66 \mathrm{wt} \%$ (daf). Adding $2 \mathrm{wt} \%$ of $\mathrm{KCl}$ to the washed straw resulted in a char yield which was close to that of the original straw sample. This indicated that $\mathrm{K}$ and $\mathrm{Cl}$, which in general are major inorganic species present in biomass, have great effects on the pyrolysis reactions. There seems little doubt that removal of $\mathrm{K}$ and $\mathrm{Cl}$, and/or other minerals present in the plant resulted in a higher yield of volatile matter and lower yield of fixed carbon.

\subsection{Trace elements in solid fuel products}

Trace element (23 elements) analysis results from parent (S0) and processed solid fuels (S1 and S3) for Bana (P276), G-Bana, P-Bana, OG03 and E-cane are presented in Table 3. Six elements (Sb, Be, F, $\mathrm{Ge}$, Th, and $\mathrm{U}$ ) were present at concentrations below the instrument detection limits. The remaining 17 elements, As, Ba, B, Cd, Cr, Co, Cu, Pb, Mn, Hg, Mo, Ni, Se, Sr, Sn, V, and Zn, were present in some but not all of the samples. As, $\mathrm{Cd}, \mathrm{Cr}, \mathrm{Pb}, \mathrm{Hg}, \mathrm{Se}, \mathrm{V}$, and $\mathrm{Zn}$, have been reported to have adverse effects on solid oxide fuel cells (SOFC)[2], as they may be present in the gas phase at SOFC working temperatures. In addition, $\mathrm{Cd}, \mathrm{Mo}, \mathrm{Pb}$, and $\mathrm{Zn}$, have been measured in a gasifier product stream downstream of $\mathrm{SiC}$ candle filter ( $3 \mu \mathrm{m}$ pore diameter) operating at $\sim 650{ }^{\circ} \mathrm{C}$ [27].

Most trace elements present in the parent materials have reduced concentrations in the processed fuels as shown in Table 3. For example, processing Bana (P276) was effective in reducing concentrations of As, B, and Sr. Levels in the parent material (S0) were reduced from $12.4 \mathrm{mg} / \mathrm{kg}, 10.6 \mathrm{mg} / \mathrm{kg}, 17.1$

$\mathrm{mg} / \mathrm{kg}$, respectively, to $1.44 \mathrm{mg} / \mathrm{kg}, 0.56 \mathrm{mg} / \mathrm{kg}, 1.9 \mathrm{mg} / \mathrm{kg}$, respectively, in the final processed fuels (S3). Concentrations of nine elements ( $\mathrm{Ba}, \mathrm{Cd}, \mathrm{Co}, \mathrm{Cu}, \mathrm{Pb}, \mathrm{Mn}, \mathrm{Hg}, \mathrm{Se}$, and $\mathrm{Zn}$ ) were also reduced, but to a lesser extent. Fuel processing did not change the concentrations of Sn and V. Increased concentrations of $\mathrm{Cr}$, Mo, and $\mathrm{Ni}$, were measured in the processed solid fuels ( $\mathrm{S} 1$ and $\mathrm{S} 3$ vs $\mathrm{S} 0$ ). As these are primary components of 316 stainless steel, it suggests that the screw press working surfaces may be their source.

Varied elemental concentrations in plant materials are the result of differences in plant variety, soils, and the surrounding environment [1]. Different soil types are found at the Poamoho and Waimanalo sites. The Poamoho site where Bana was harvested has an oxisol with predominant content of kaolinitic clay and iron oxides. The Waimanalo site where G-Bana, P-Bana, and OG03 were harvested has a mollisol with predominant content of montmorilonitic clay. Soil samples from the two sites were analyzed for As, $\mathrm{Ba}, \mathrm{Cd}, \mathrm{Co}, \mathrm{Cr}, \mathrm{Cu}, \mathrm{Mn}$. Mo, Ni, Pb, Se, Sn, V, and Zn, and results are presented in Table 4. Ba, Cd, Co, $\mathrm{Cu}, \mathrm{Mn}, \mathrm{Ni}, \mathrm{Pb}$ and $\mathrm{Zn}$ are present in higher soil concentrations at the Poamoho site than that at Waimanalo, and only two elements, $\mathrm{Cr}$ and V, are slightly lower. The remaining elements As, Mo, Se, and Sn, are below instrument detection limits. Only Ba, Mn, and $\mathrm{Zn}$ were present in higher levels in the Bana (S0) sample harvested from the Poamoho plot than were present in the plants (G-Bana (S0), P-Bana (S0), and OG03 (S0)) harvested from the plot at Waimanalo, in keeping with higher soil concentrations. 
Other sources of elements present in the plants, such as dry deposition, were not taken into account. None of the potential dedicated feedstock species demonstrated hyper-accumulation of metals.

\subsection{Analysis of the liquid products}

Analysis results of liquid products, L1, L2 and L3, are presented in Tables, 5, 6 and 7. EC values, TS, TSS, concentrations of sucrose and glucose, and COD values are listed in Table 5. Concentrations of $\mathrm{K}^{+}$, $\mathrm{Na}^{+}, \mathrm{Ca}^{2+}, \mathrm{Ca}^{2+}+\mathrm{Mg}^{2+}$ (hardness), $\mathrm{Mg}^{2+}$, and $\mathrm{Cl}^{-}$, are presented in Table 6. An extended elemental analysis (24 elements) for selected samples is listed in Table 7.

Tables 5 and 6 summarize the effects of increasing screw press operating pressures with data from the Bana-P0, Bana-P138, Bana-P276, and Bana-P414. Results are mixed, depending on the performance indicator selected. EC values of L1 liquids generated from P0 to P414 operating conditions are all 30 $\mathrm{mS} \mathrm{cm}{ }^{-1}$. $\mathrm{Cl}^{-}$is the only ion that exhibits consistently increasing concentrations in the L1 juice with increasing pressure. $\mathrm{K}^{+}, \mathrm{Na}^{+}, \mathrm{Ca}^{2+}$, and $\mathrm{Mg}^{2+}$, display no clear trends as a function of screw press pressure setting. Compared with the initial liquid samples (L1), water leachate (L2) and second expressed liquid (L3) had much lower elements concentration and EC values, decreasing by an order of magnitude after rehydration with leaching water.

TS and TSS were selectively measured in liquids from P-Bana (II), E-cane (II), and S-cane samples. The initial juice (L1) had the greatest contents of TS and TSS and the water leachate (L2) had the least. Finely divided particulate matter was expressed from the materials by the screw press and passed through the mesh of the screen used in the S1 leaching process. The filtrate contained soluble solids including minerals, sugars, organic acids, etc. As expected, S-cane and E-cane had greater concentrations of TS and higher COD values than P-Bana due to their higher sugar (sucrose and glucose) contents in the liquid streams, as shown in Table 5. Sugar concentrations in juice from E-cane are comparable to literature reports [28]. TSS contributes 9 to $38 \%$ of TS. Comparing the COD values of the four materials shows a large difference between the E-cane sample and three other samples. The COD measurement on the Ecane sample was not filtered prior to analysis and the difference can be attributed to the TSS present in the sample. COD values in U.S. sugar cane processing factory effluent ranged from 0.7 to $2.0 \mathrm{~g} / \mathrm{L}$ [29] and these are comparable to values measured for the more dilute L2 and L3 liquids from P-Bana (II), Ecane (II), and S-cane.

Inorganic matter was present as water soluble minerals, as shown in Table 6. For all samples, the initial expressed juice (L1) exhibited the highest concentrations of $\mathrm{K}^{+}, \mathrm{Na}^{+}, \mathrm{Ca}^{2+}, \mathrm{Mg}^{2+}$, and $\mathrm{Cl}^{-}$, and consequently, the highest EC values $\sim 30 \mathrm{mS} / \mathrm{cm}$. Table 6 also shows that banagrass (Bana, P-Bana, and G-Bana), and OG03 grown in experiment station plots on Oahu had greater concentration of $\mathrm{K}^{+}$and $\mathrm{Cl}^{-}$in the liquid streams than those from the E-cane, E-cane (II), P-Bana (II), and S-cane samples grown in field plots on the HC\&S plantation on Maui. This may be the result of different fertilization regimens.

Comparing the sum of the TSS and the soluble solids (sucrose, glucose, $\mathrm{K}^{+}, \mathrm{Na}^{+}, \mathrm{Ca}^{+}$, and $\mathrm{Cl}^{-}$) data for L1, L2, and L3 samples from the P-Bana (II), E-Cane (II), and S-cane materials with the corresponding, directly measured TS data indicates that the sum is 35 to $101 \%$ of the TS value. The P- 
Bana (II) is at the low end of this range; $35 \%$ for L2 and 53\% for L1 and L3. The E-cane (II) and S-cane (II) samples ranged from 63 to $101 \%$ and 58 to $79 \%$, respectively. Lack of agreement between the direct TS measurement and the sum of the individual solid measurements may arise if an individual component wasn't identified and included or if the total solids sample were difficult to dry due to its chemical makeup thereby affecting the moisture measurement.

A possible use of the resulting liquids is to supplement water mechanically applied for crop irrigation. This practice would recycle organic matter and other nutrients and reduce synthetic fertilizer application rates. The analyses from Table 6 combined with the extended elemental analyses presented in Table 7 indicate that the liquid products contain the macronutrients $\mathrm{K}$ and $\mathrm{P}$, the secondary nutrients $\mathrm{Ca}$ and $\mathrm{Mg}$. In addition, the micronutrients $\mathrm{B}, \mathrm{Cu}, \mathrm{Fe}, \mathrm{Cl}, \mathrm{Mn}$, and $\mathrm{Zn}$, present in the liquid streams are essential for plant growth [30]. An overabundance may result in element toxicity concerns particularly for soluble metals. Many of them are biologically beneficial in small quantities but become harmful at higher levels of exposure. US EPA [30] recommendations for irrigation water quality indicate that salinity is a key parameter in determining the suitability of the water for irrigation. Water with an EC value greater than $3.0 \mathrm{mS} / \mathrm{cm}$ is severely restricted for irrigation. All L1 liquids listed in Table 5 exhibit EC values of $\sim 30$ $\mathrm{mS} / \mathrm{cm}$ and the L2 and L3 liquids are in a range of 1 to $5 \mathrm{mS} / \mathrm{cm}$. Free chlorine in irrigation water at concentration of $>5 \mathrm{mg} / \mathrm{L}$ can cause severe damage to plants [30] and this value is exceeded consistently in liquids generated from fuel treatments (Table 6). Suggested limits [30] for many of the trace elements are included in Table 7. Concentrations of $\mathrm{Al}, \mathrm{B}, \mathrm{Cd}, \mathrm{Co}, \mathrm{Cr}, \mathrm{Cu}, \mathrm{Fe}, \mathrm{Mn}, \mathrm{Mo}, \mathrm{Ni}$, and $\mathrm{Zn}$ in L1 liquids from at least one of the grass species exceed the suggested limits. Blending process liquids with one another or with better quality irrigation water would be expected to reduce the composite concentration below identified limits. The Mn concentration in the L1 liquid from Bana-P276 exceeds the recommendation for irrigation water by $250 \%$ and would require the highest rate of dilution. The high Mn concentration in the L1 liquid is consistent with the high concentrations observed in the Poamoho soil and the S0 parent material shown in Table 4. Stainless steel (316) working surfaces of the screw press may also have contributed to the $\mathrm{Mn}, \mathrm{Cr}, \mathrm{Fe}$, and $\mathrm{Ni}$ concentrations of the liquids.

EPA guidelines [30] suggest that irrigation of non-food crops (e.g. purpose grown fuel grass) with reclaimed water is more readily accepted by the agricultural community. If irrigation is the intended use for these liquid streams, management strategies should be based on the long term effects on the soilwater-plant systems. Balancing element supply and accessibility with plant nutrient requirements should be investigated further.

\subsection{Process efficiency on dewatering and mineral removal}

Equation (2) was used to evaluate the removal efficiency of moisture, elements, and ash. Test results for the Bana sample shown in Fig. 5 confirm that the yields of initial liquid (L1) increased with increasing pressure on the screw press outlet cone and consequently the moisture content of expressed solid material (S1) was reduced. Results showed that the liquid yields increased from 16 to $26 \%$ of the 
initial mass, and the moisture content gradually reduced from the S0 value of $60 \%$ to $45 \%$ in the S1 P414 sample when the effective exit cone pressure increased from 0 to $147 \mathrm{kPa}$, respectively.

Dewatering was also investigated on varied plant samples G-Bana, P-Bana, OG03, E-cane, P-Bana (II), E-cane (II), and S-cane. Liquid removal yields in the first pressing at an effective exit cone pressure of $70 \mathrm{kPa}(\mathrm{P} 207)$ are summarized in Table 8. Results indicate that material type has a strong impact on the juice removal. For example, S-cane and E-cane, containing the same moisture with $69 \%$, had $7.6 \%$ difference (absolute) in production of the initial liquid (L1). For different samples of the same plant, PBana, with very similar S0 moisture content (65-66.8 \%), the liquid yields were $29.7 \%$ and $38.4 \%$ for P-Bana and P-Bana (II), respectively. This difference may be caused by the irrigation history and age.

Table 9 lists the effect of effective exit cone pressure on removal efficiency $(\eta, \%)$ of ash and elements $\mathrm{K}, \mathrm{Na}, \mathrm{Ca}$, and $\mathrm{Cl}$ for the Bana sample. The material mass balances and elemental mass balances are also listed. Results show that the ash removal efficiency in the first pressing was from 9.4 to $24.7 \%$ based on unprocessed material (S0) element mass at all operating pressures. $\mathrm{K}, \mathrm{Na}, \mathrm{Ca}$, and $\mathrm{Cl}$ removals ranged from $14.3-31.7 \%, 3.1-27.6 \%, 10.0-27.1 \%$, and 16.8-44.2\%, respectively. In most cases, higher effective exit cone pressure generated higher removal efficiency. Material mass balance closures were in the range of 0.92 and 0.98 . Elemental mass balance closures were in the range of 1.17-1.28 for $\mathrm{K}$, 1.06-1.33 for $\mathrm{Na}, 0.74-0.91$ for $\mathrm{Ca}$, and 1.33-1.88 for $\mathrm{Cl}$.

Fig. 6 shows the effect of increasing the effective exit cone pressure on element $(\mathrm{K}, \mathrm{Cl}, \mathrm{Na}, \mathrm{Ca}$, and $\mathrm{Mg}$ or "Ca+Mg") concentrations in expressed initial liquid (L1), and solid fuel (S1). With increasing pressure, $\mathrm{K}$ and $\mathrm{Cl}$ concentrations in $\mathrm{S} 1$ samples drop significantly and accordingly increase in $\mathrm{L} 1$ samples. Trends for $\mathrm{Na}, \mathrm{Ca}$, and $\mathrm{Mg}(\mathrm{Ca} / \mathrm{Mg}$ was measured in liquid samples) data are less clear. The current data indicate that increasing pressure can aid in plant cell rupture and enhance removal of liquids and selected elements.

Table 10 summarizes the removal efficiencies and mass balances for G-Bana, P-Bana, OG03 and Ecane using an effective exit pressure of $72 \mathrm{kPa}$ (P207) on the screw press. Data varied with material types, and generally showed that ash can be removed in the first pressing at $14.3-35.3 \%$, $\mathrm{K}$ at 30.7 $62.5 \%, \mathrm{Na}$ at $16.6-50.5 \%, \mathrm{Ca}$ at $5.5-49.4 \%$, and $\mathrm{Cl}$ at $42.3-61 \%$ for these four types of fuel samples.

The following step of leaching and second pressing can remove additional minerals with greater efficiency than the first pressing step. Specifically, as listed in Table 9 for $91 \mathrm{kPa}$ effective screw press outlet pressure, the reduction efficiency based on $\mathrm{S} 1$ inputs of ash and the elements $\mathrm{K}, \mathrm{Na}, \mathrm{Ca}$, and $\mathrm{Cl}$, were determined to be $65.8 \%, 74.1 \%, 39.3 \%, 25.0 \%$, and $79.5 \%$, respectively. In comparison with the first pressing, the step of leaching and pressing had higher mineral removal efficiency. This conclusion is supported by the analytical results obtained for G-Bana, P-Bana, OG03 and E-cane, as listed in Table 10. Errors associated with the removal efficiencies were determined for the E-cane samples and are presented in Table 10. Relative errors are typically $<10 \%$ of the measured value.

Fig. 7 showed the distribution of elements $\mathrm{K}, \mathrm{Na}, \mathrm{Ca}$ and $\mathrm{Cl}$ among the four process outputs, L1, L2, L3, and S3, under four effective exit cone pressure conditions. Results showed that more than $80 \%$ of the 
elements $\mathrm{K}, \mathrm{Na}$, and $\mathrm{Cl}$ were removed into the liquid streams. Davidsson, et al [12] found that fuel washing was ineffective in removing alkali bound to the organic structure of biomass. Thus, the current results suggested that as much as $10 \%$ of alkali could be present in this form. In some cases, less than $10 \%$ of the $\mathrm{Ca}$ present in the parent material was removed to the liquid streams, indicating that $\mathrm{Ca}$ was mostly water insoluble [19] and retained in the solid products (S3).

Fig. 7 data showed that each process step made different contribution to removal. At the highest effective cone exit pressure of $144 \mathrm{kPa}(\mathrm{P} 414)$, the first pressing can remove nearly $50 \%$ of the $\mathrm{K}$ and $\sim 65 \%$ of $\mathrm{Cl}$ into the liquid L1 stream. The rinse step improved the elements removal between $20-40 \%$ for $\mathrm{K}$, and around $10 \%$ for $\mathrm{Cl}$. Note that $\mathrm{Na}$ had large fractions in the L2 streams, but the concentration was comparable or at the same level with that present in the tap water (See the data in Table 7). Additional element removal can be achieved in the second dewatering press but generally with less element mass removed than the first pressing. Similar trends were observed for the $72 \mathrm{kPa}$ exit cone effective pressure test conditions used for P-Bana, G-Bana, OG03, and E-cane as shown in Fig. 8.

Table 11 presents the loss of dry matter mass during processing for P-Bana, E-cane, and S-cane calculated using Equation (3). In P-Bana, for example, 11\% of dry matter was recovered from the L1 stream, $5 \%$ in the L2 stream, and $2 \%$ in the L3 stream. For the final fuel products (S3), the dry matter yields would be $\sim 82 \%, 80 \%$, and $70 \%$ for P-Bana, E-cane, and S-cane, respectively. The higher losses for the E-cane and S-cane samples are consistent with greater amounts of soluble solids measured in their liquid process streams.

\subsection{Prediction of gaseous contaminants in gasification}

Fig. 9 compares results of FactSage [22] chemical equilibrium calculations for Bana S0 and BanaP276 S3 undergoing steam gasification at a temperature of $900^{\circ} \mathrm{C}$ and a steam to dry fuel ratio of two. Total element concentrations of $\mathrm{K}, \mathrm{Cl}, \mathrm{S}, \mathrm{Mg}$, and $\mathrm{Na}$ present as species predicted in the equilibrium product gas are reduced significantly by fuel processing. $\mathrm{K}$ and $\mathrm{Cl}$ concentrations in the product gas are reduced by $78 \%$ and $85 \%$, respectively.

Turn [21] compared experimental results of air blown gasification tests with equilibrium calculations based on fuel and oxidizer input under fluidized bed conditions. Using comparable fuel processing techniques, reductions in fuel-bound $\mathrm{K}, \mathrm{Na}$, and $\mathrm{Cl}$ reduced experimental, product gas phase concentrations by roughly one order of magnitude. Thermochemical equilibrium calculation of gas phase composition using FactSage predicted reductions of roughly three orders of magnitude for $\mathrm{K}$ and $\mathrm{Na}$ and one order of magnitude for $\mathrm{Cl}$. Recognizing that differences between fuels and gasification conditions will affect both measured concentrations and equilibrium predictions, the equilibrium calculations indicate that fuel processing can reduce the need for gas conditioning but is not expected to eliminate it completely.

\section{CONCLUSION}


Using mechanical dewatering and leaching techniques to process fresh grasses can improve biomass fuel properties for thermochemical conversion. Processing was effective in removing liquids, water soluble elements (i.e., alkali, impurity elements chlorine and sulfur), as well as some trace elements and heavy metals. Freshly harvested green-banagrass, purple-banagrass, guinea grass, energy cane, and sugar cane (as reference) were tested. The investigation has associated implications for design of thermochemical conversion systems that are summarized below:

1. In the first pressing, the yields of initial juice (L1) depended on the biomass type, the initial water content, and the practical operating pressure of the press and ranged from 16.7 and $60.6 \%$ (wet basis) of the initial fuel mass with concomitant reductions in fuel moisture that will improve thermochemical processes.

2. The fuel analyses of solid products (S1) indicated that the fuel properties were upgraded with lower ash and moisture contents, improved heating values, and higher ash deformation temperatures, when compared with the unprocessed materials. Water rinsing the S1 solid and subjecting it to a second mechanical dewatering further improved the properties of the resulting S3 fuels by removing additional water-soluble minerals. Higher fuel quality has the potential to reduce operating and maintenance costs for thermochemical conversion systems.

3. The $\mathrm{S} 3$ fuels also exhibited a higher ratio of volatile matter to fixed carbon (VM/FC), the result of the removal of alkali elements from the fuel. Increased volatility implies increased fuel reactivity, reduced residence time requirements, and reduced reactor volumes.

4. Results showed that the process removed $\sim 10 \%$ of dry matter from the parent material (except sugarcane) into the initial liquids (L1) in the production of fuel (S1). An additional $~ 10 \%$ of dry matter transferred to the rinse leachate (L2) and the second juice (L3) in the production of the final processed fuel S3. This indicates a potential for significant dry matter recovery from liquid byproduct streams.

5. All liquid byproduct streams were characterized for COD (chemical oxygen demand), sugars, total solid, total suspended solids, major and trace elements. Element concentrations in the liquid streams exceeded EPA guidelines for land application, indicating that management (blending with lower concentration streams or removal of elements) will be required to implement nutrient recycling by direct land application.

6. Implementation of mechanical dewatering and leaching systems for tropical grasses will depend on weighing the costs of fuel processing against the benefits of reduced operating and maintenance costs and improved system performance.

\section{Acknowledgements:}

This work was supported by the U.S. Department of Energy under Award No. DE-FG36-08GO88037. 


\section{References:}

[1] A. Kabata-Pendias, H. Pendias, Trace elements in soils and plants, 3rd ed., CRC Press LLC, 2001.

[2] F.N. Cayan, M. Zhi, S.R. Pakalapati, I. Celik, N. Wu, R. Gemmen, Effects of coal syngas impurities on anodes of solid oxide fuel cells, Journal of Power Sources, 185 (2008) 595-602.

[3] S.V. Vassilev, D. Baxter, L.K. Andersen, C.G. Vassileva, T.J. Morgan, An overview of the organic and inorganic phase composition of biomass, Fuel, 94 (2012) 1-33.

[4] S.Q. Turn, C.M. Kinoshita, D.M. Ishimura, J. Zhou, The fate of inorganic constituents of biomass in fluidized bed gasification, Fuel, 77 (1998) 135-146.

[5] S.Q. Turn, C.M. Kinoshita, D.M. Ishimura, T.T. Hiraki, J. Zhou, S.M. Masutani, An Experimental Investigation of Alkali Removal from Biomass Producer Gas Using a Fixed Bed of Solid Sorbent, Industrial \& Engineering Chemistry Research, 40 (2001) 1960-1967.

[6] E. Kurkela, P. Stahlberg, J. Laatikainen-Luntama, Pressurized fluidized-bed gasification experiments with wood, peat and coal at VTT in 1991-1994. Part 2. Experiences from peat and coal gasification and hot gas filtration, in, Valtion Teknillinen Tutkimuskeskus,Espoo,Finland., 1995, pp. 74 pp.

[7] K. Salo, W. Mojtahedi, Fate of alkali and trace metals in biomass gasification, Biomass and Bioenergy, 15 (1998) 263-267.

[8] M.J.A. Tijmensen, A.P.C. Faaij, C.N. Hamelinck, M.R.M. van Hardeveld, Exploration of the possibilities for production of Fischer Tropsch liquids and power via biomass gasification, Biomass and Bioenergy, 23 (2002) 129-152.

[9] S.Q. Turn, C.M. Kinoshita, D.M. Ishimura, Removal of inorganic constituents of biomass feedstocks by mechanical dewatering and leaching, Biomass and Bioenergy, 12 (1997) 241-252.

[10] S. Arvelakis, P. Vourliotis, E. Kakaras, E.G. Koukios, Effect of leaching on the ash behavior of wheat straw and olive residue during fluidized bed combustion, Biomass and Bioenergy, 20 (2001) 459-470.

[11] B.M. Jenkins, R.R. Bakker, J.B. Wei, On the properties of washed straw, Biomass and Bioenergy, 10 (1996) 177-200.

[12] K.O. Davidsson, J.G. Korsgren, J.B.C. Pettersson, U. Jaglid, The effects of fuel washing techniques on alkali release from biomass, Fuel, 81 (2002) 137-142.

[13] C. Yu, P. Thy, L. Wang, S.N. Anderson, J.S. VanderGheynst, S.K. Upadhyaya, B.M. Jenkins, Influence of leaching pretreatment on fuel properties of biomass, Fuel Processing Technology, 128 (2014) 43-53.

[14] L. Deng, T. Zhang, D. Che, Effect of water washing on fuel properties, pyrolysis and combustion characteristics, and ash fusibility of biomass, Fuel Processing Technology, 106 (2013) 712-720.

[15] S. Arvelakis, H. Gehrmann, M. Beckmann, E.G. Koukios, Effect of leaching on the ash behavior of olive residue during fluidized bed gasification, Biomass and Bioenergy, 22 (2002) 55-69.

[16] R.R. Bakker, B.M. Jenkins, R.B. Williams, Fluidized Bed Combustion of Leached Rice Straw, Energy Fuels, 16 (2002) 356-365.

[17] S. Arvelakis, H. Gehrmann, M. Beckmann, E.G. Koukios, Agglomeration problems during fluidized bed gasification of olive-oil residue: evaluation of fractionation and leaching as pretreatments, Fuel, 82 (2003) 1261-1270.

[18] D.C. Dayton, B.M. Jenkins, S.Q. Turn, R.R. Bakker, R.B. Williams, D. Belle-Oudry, L.M. Hill, Release of Inorganic Constituents from Leached Biomass during Thermal Conversion, Energy Fuels, 13 (1999) 860-870.

[19] B.M. Jenkins, J.D. Mannapperuma, R.R. Bakker, Biomass leachate treatment by reverse osmosis, Fuel Processing Technology, 81 (2003) 223-246.

[20] L.S. Clesceri, A.E. Greenberg, A.D. Eaton, Standard Methods for the Examination of Water and Wastewater, 20th Edition, APHA American Public Health Association, 1998.

[21] S.Q. Turn, Chemical equilibrium prediction of potassium, sodium, and chlorine concentrations in the product gas from biomass gasification, Industrial \& Engineering Chemistry Research, 46 (2007) 8928-8937.

[22] C.W. Bale, A.D. Pelton, T. W.T., F*A*C*T 2.1-User's Manual, in, Ecole Polytechnique de Montreal/Royal Military College, Canada, July, 1996.

[23] H. Wu, K. Yip, Z. Kong, C.-Z. Li, D. Liu, Y. Yu, X. Gao, Removal and Recycling of Inherent Inorganic Nutrient Species in Mallee Biomass and Derived Biochars by Water Leaching, Ind. Eng. Chem. Res., 50 (2011) 12143-12151.

[24] M.P. Kannan, G.N. Richards, Gasification of biomass chars in carbon dioxide: dependence of gasification rate on the indigenous metal content, Fuel, 69 (1990) 747-753.

[25] R. Fahmi, A.V. Bridgwater, L.I. Darvell, J.M. Jones, N. Yates, S. Thain, I.S. Donnison, The effect of alkali metals on combustion and pyrolysis of Lolium and Festuca grasses, switchgrass and willow, Fuel, 86 (2007) 1560-1569.

[26] A. Jensen, K. Dam-Johansen, M.A. Wojtowicz, M.A. Serio, TG-FTIR study of the influence of potassium chloride on wheat straw pyrolysis, Energ Fuel, 12 (1998) 929-938.

[27] H. Cui, S.Q. Turn, V. Keffer, D. Evans, T. Tran, M. Foley, Study on the fate of metal elements from biomass in a benchscale fluidized bed gasifier, Fuel, 108 (2013) 1-12.

[28] M. Kim, D. Day, Composition of sugar cane, energy cane, and sweet sorghum suitable for ethanol production at

Louisiana sugar mills, J Ind Microbiol Biotechnol, 38 (2011) 803-807. 
[29] O. Cheesman, Environmental impacts of sugar production : the cultivation and processing of sugarcane and sugar beet, CABI, Wallingford, UK ; Cambridge, MA, 2004.

[30] 2012 Guidelines for water reuse, EPA/600/R-12/618, in, U.S. Environmental Protection Agency, Washington, DC. 


\section{Figure Captions:}

Fig. 1 Schematic of fuel processing and samples generated from banagrass (Material streams are identified by screw press discharge pressure setting (P\#) and liquid (L\#) or solid (S\#))

Fig. 2 Pressure discharge system in the compact screw press

Fig. 3 Effective screw press discharge cone backpressure measured as a function of the pneumatic cylinder pressure (gauge reading) setting. Error bars indicate 95\% confidence interval.

Fig. 4 Comparison of the ratio of the VM/FC values for the processed and parent biomass, i.e. $\left(\mathrm{VM} / \mathrm{FC}_{\text {processed }}\right) /\left(\mathrm{VM} / \mathrm{FC}_{\text {parent }}\right)$ (Note: Literature data were either cited or calculated)

Fig. 5 Liquid yields (based on wet input, S0) and moisture contents (based on wet output, S1) of pressed solid products (Sample: Bana) after the first pressing as a function of screw press exit pressure

Fig. 6 Changes of element concentrations in liquid (L1) and solid samples (S1) with varied effective exit cone pressure in the first pressing step (Sample: Bana) ((a) Na; (b) K; (c) Ca; (d) Mg and $(\mathrm{Ca}+\mathrm{Mg}) ;(\mathrm{e}) \mathrm{Cl})$

Fig. 7 Elements fraction in the outputs of banagrass (Bana) at four effective exit cone pressures (a: BanaP0; b: Bana-P138; c: Bana-P276; d: Bana-P414)

Fig. 8 Elements fraction in the outputs from the screw press with exit cone effective pressure of $72 \mathrm{kPa}$ of (a) P-Bana, (b) G-Bana, (c) OG03, and (d) E-cane

Fig. 9 Chemical equilibrium prediction of $\mathrm{K}, \mathrm{Cl}, \mathrm{S}, \mathrm{Mg}$, and $\mathrm{Na}$ in the product gas from steamgasification of parent S0 banagrass and P276-S3 banagrass material (FactSage calculation conditions: $900^{\circ} \mathrm{C}$, steam/fuel $=2$ )

\section{Tables:}

Table 1 Summary of the test material samples in the study

Table 2 Fuel property analyses for green banagrass (G-Bana), purple banagrass (P-Bana) guinea grass (OG03), and energy cane (E-cane) (S1 and S3 samples produced at an effective cone pressure of $72 \mathrm{kPa})$

Table 3 Trace elements in unprocessed samples (S0) and processed samples (S1 and S3) for green banagrass (Bana-P276 and G-Bana), purple banagrass (P-Bana), guinea grass (OG03), and energy cane (E-cane) (units in $\mathrm{mg}$ of element/kg of dry fuel)

Table 4 Summary of results of elemental analysis of soil and plant material samples collected in Poamoho (P) and Waimanalo (W)

Table 5 Analysis of liquid by-products L1, L2 and L3 from processing green banagrass (Bana-P276 and G-Bana), purple banagrass (P-Bana), guinea grass (OG03), and energy cane (E-cane)

Table 6 Elemental analyses $(\mathrm{mg} / \mathrm{L})$ of liquid by-products L1, L2 and L3 from processing green banagrass (Bana-P276 and G-Bana), purple banagrass (P-Bana), guinea grass (OG03), and energy cane (Ecane) using ISE and ICP-AES

Table 7 Trace elements analyses $(\mathrm{mg} / \mathrm{L})$ of liquid by-products from pressing green banagrass (Bana-P276 and G-Bana), purple banagrass (P-Bana), guinea grass (OG03), and energy cane (E-cane) by using ICP-AES, as well as the maximum concentrations suggested for irrigation

Table 8 S0 moisture content and first liquid removal efficiency for samples using a screw press with an effective exit cone pressure of $70 \mathrm{kPa}$ 
Table 9 Summary of liquid yields, material and element mass balances, and ash and element removal efficiency test results for increasing screw press outlet pressures for green banagrass (Bana)

Table 10 Summary of test results for G-Bana. P-Bana, OG03, and E-cane with an effective screw press exit pressure of $72 \mathrm{kPa}(\mathrm{P} 207)$.

Table 11 Mass loss of dry matter during the fuel processing 
Tables

Table 1 Summary of the test material samples in the study

\begin{tabular}{|c|c|c|c|}
\hline Biomass samples & Variety & Sample ID & Harvest date and location \\
\hline \multirow{4}{*}{$\begin{array}{l}\text { Banagrass } \\
\text { (Pennisetum purpureum } x \\
\text { Pennisetum glaucum) }\end{array}$} & $\begin{array}{l}\text { Green } \\
\text { banagrass }\end{array}$ & Bana & $\begin{array}{l}\text { February, 2010; } \\
\text { University of Hawaii's } \\
\text { Poamoho Research Station, } \\
\text { in Waialua, Oahu, Hawaii }\end{array}$ \\
\hline & $\begin{array}{l}\text { Green } \\
\text { banagrass }\end{array}$ & G-Bana & $\begin{array}{l}\text { December, 2010; } \\
\text { Waimanalo, Oahu, Hawaii }\end{array}$ \\
\hline & $\begin{array}{l}\text { Purple } \\
\text { banagrass }\end{array}$ & P-Bana & $\begin{array}{l}\text { December, 2010, } \\
\text { Waimanalo, Oahu, Hawaii }\end{array}$ \\
\hline & $\begin{array}{l}\text { Purple } \\
\text { banagrass }\end{array}$ & P-Bana (II) & $\begin{array}{l}\text { September, 2013, } \\
\text { Maui, Hawaii }\end{array}$ \\
\hline $\begin{array}{l}\text { Guinea grass } \\
\text { (Panicum maximum) }\end{array}$ & Guinea grass & OG03 & $\begin{array}{l}\text { December, 2010, } \\
\text { Waimanalo, Oahu, Hawaii }\end{array}$ \\
\hline \multirow{2}{*}{$\begin{array}{l}\text { Energy cane } \\
\text { (Saccharum sponteneum) }\end{array}$} & Energy cane & E-cane & $\begin{array}{l}\text { April, 2013, } \\
\text { Maui, Hawaii }\end{array}$ \\
\hline & $\begin{array}{l}\text { Energy cane } \\
\text { (II) }\end{array}$ & E-cane (II) & $\begin{array}{l}\text { September, 2013, } \\
\text { Maui, Hawaii }\end{array}$ \\
\hline $\begin{array}{l}\text { Sugarcane } \\
\text { (Saccharum officinarum L.) }\end{array}$ & Sugar cane & S-cane & $\begin{array}{l}\text { September, 2013, } \\
\text { Maui, Hawaii }\end{array}$ \\
\hline
\end{tabular}




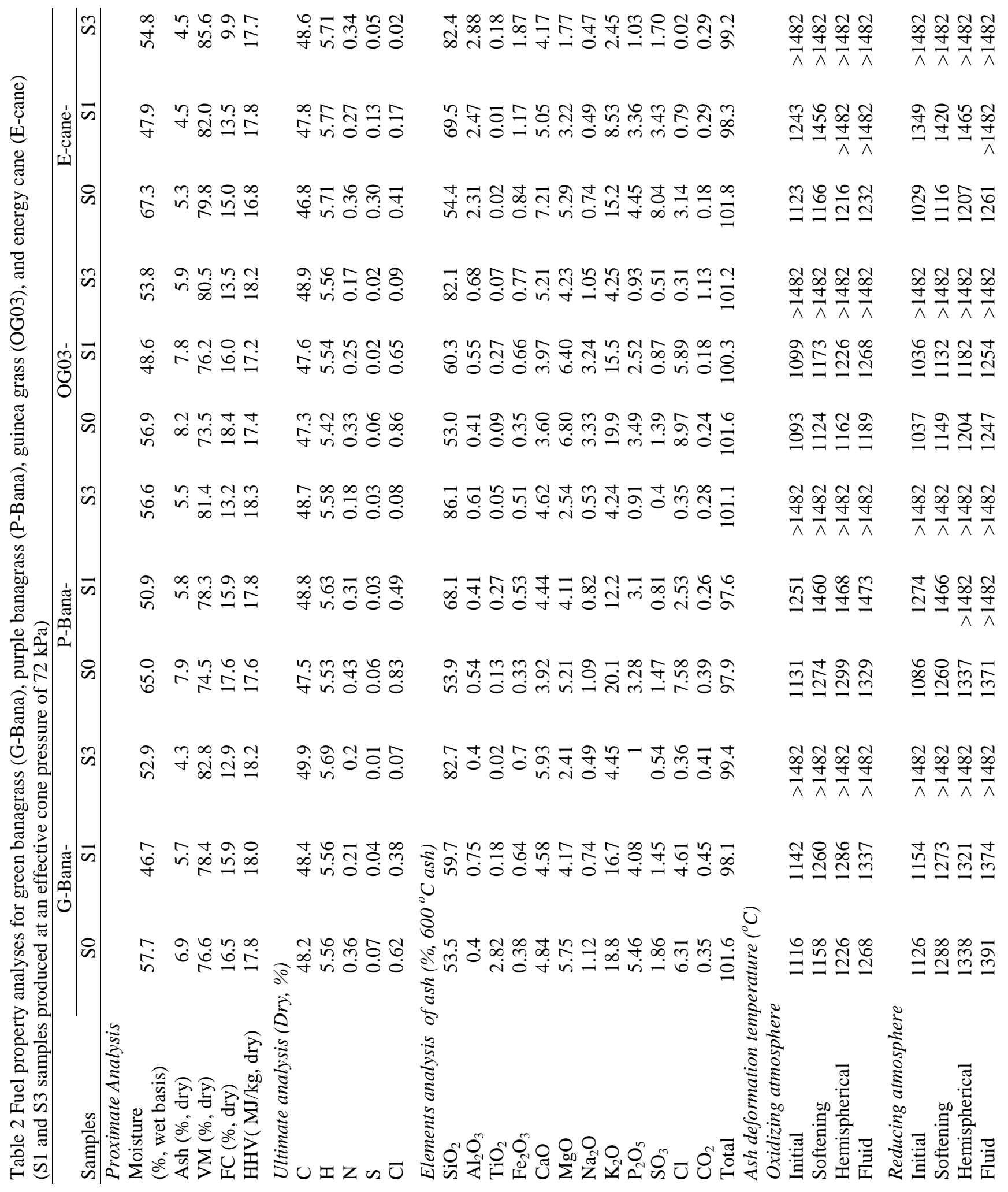




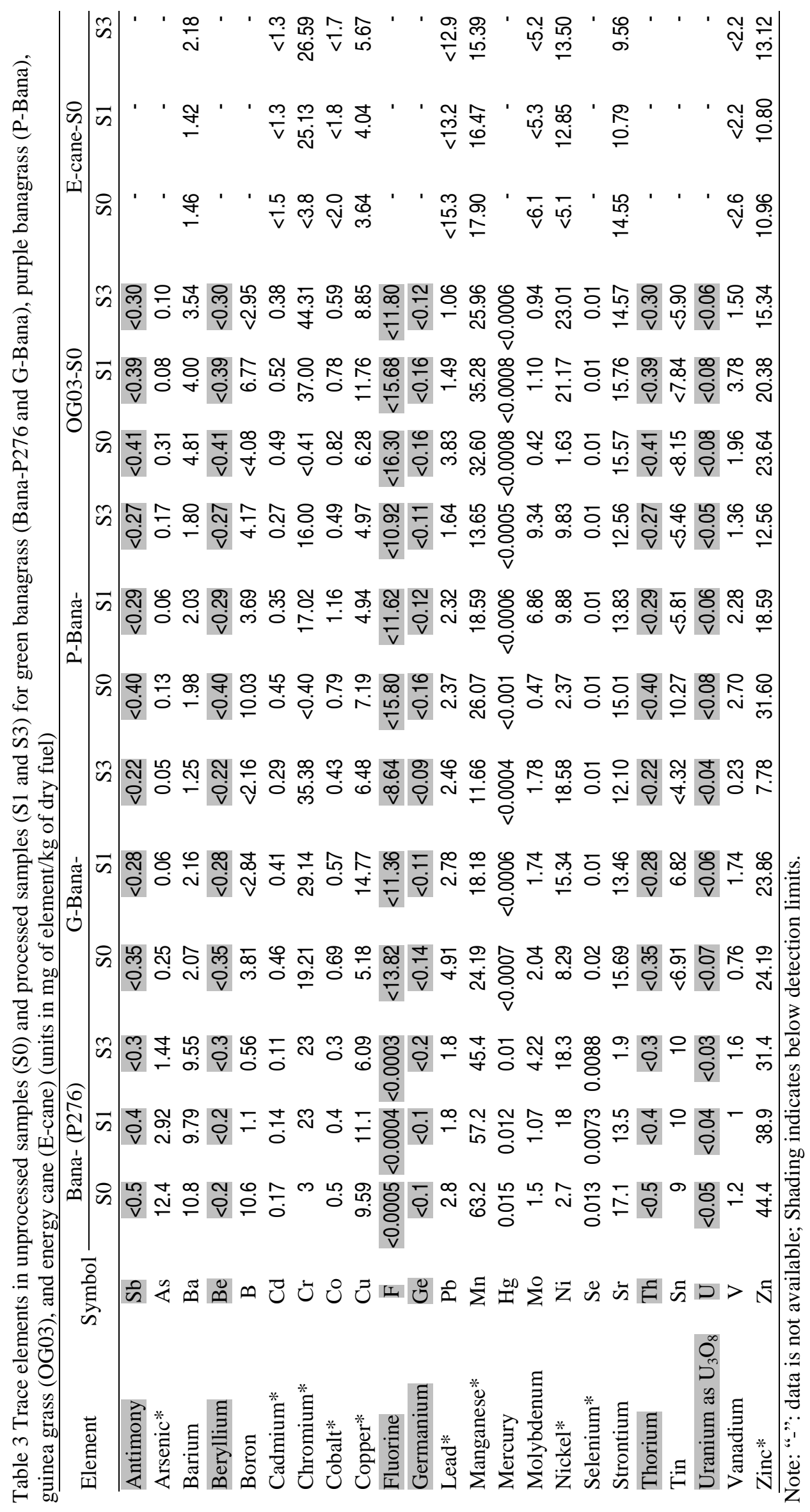




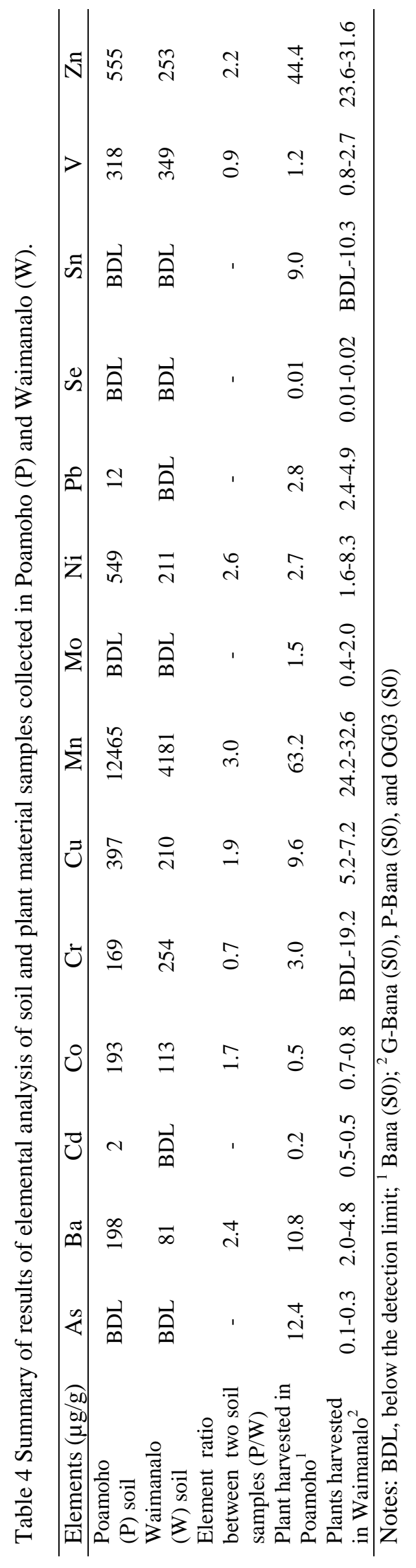


Table 5 Analysis of liquid by-products L1, L2 and L3 from processing green banagrass (Bana-P276 and GBana), purple banagrass (P-Bana), guinea grass (OG03), and energy cane (E-cane).

\begin{tabular}{|c|c|c|c|c|c|c|c|}
\hline \multicolumn{2}{|l|}{ Sample ID } & $\begin{array}{c}\mathrm{TS}^{(1)}, \\
\mathrm{g} / \mathrm{L}\end{array}$ & $\begin{array}{r}\mathrm{TSS}^{(2)} \\
\mathrm{g} / \mathrm{L}\end{array}$ & $\begin{array}{r}\mathrm{EC}^{(3)} \text { value, } \\
\mathrm{mS} / \mathrm{cm}\end{array}$ & $\begin{array}{r}\text { Sucrose, } \\
\text { wt } \% \\
\end{array}$ & $\begin{array}{r}\text { Glucose, } \\
\text { wt \% }\end{array}$ & $\begin{array}{r}\mathrm{COD}^{(4)} \text { value, } \\
\mathrm{g} / \mathrm{L}\end{array}$ \\
\hline \multicolumn{2}{|l|}{ Tap water } & - & - & 0.48 & - & - & - \\
\hline \multirow{3}{*}{ Bana-P0 } & L1 & - & - & 29.6 & - & - & - \\
\hline & L2 & - & - & 3.3 & - & - & - \\
\hline & L3 & - & - & 4.1 & - & - & - \\
\hline \multirow{3}{*}{ Bana-P138 } & L1 & - & - & 29.8 & - & - & - \\
\hline & L2 & - & - & 2.9 & - & - & - \\
\hline & L3 & - & - & 4.3 & - & - & - \\
\hline \multirow{3}{*}{ Bana-P276 } & $\mathrm{L} 1$ & - & - & 29.1 & - & - & - \\
\hline & $\mathrm{L} 2$ & - & - & 2.4 & - & - & - \\
\hline & $\mathrm{L} 3$ & - & - & 4.7 & - & - & - \\
\hline \multirow{3}{*}{ Bana-P414 } & L1 & - & - & 30.4 & - & - & - \\
\hline & $\mathrm{L} 2$ & - & - & 2.3 & - & - & - \\
\hline & L3 & - & - & 4.4 & - & - & - \\
\hline \multirow{3}{*}{ E-cane } & $\mathrm{L} 1$ & - & - & $10.02 \pm 1.70$ & $7.99 \pm 1.28$ & - & $123.7 \pm 17.7$ \\
\hline & $\mathrm{L} 2$ & - & - & $1.48 \pm 0.12$ & $0.63 \pm 0.09$ & - & $1.0 \pm 0.2^{(5)}$ \\
\hline & L3 & - & - & $2.65 \pm 0.03$ & $0.64 \pm 0.04$ & - & $16.7 \pm 1.8^{(5)}$ \\
\hline \multirow{3}{*}{ P-Bana (II) } & L1 & 96.6 & 10.7 & - & - & 2.91 & $6.06^{(6)}$ \\
\hline & $\mathrm{L} 2$ & 6.5 & 0.9 & - & - & 0.00 & $0.45^{(6)}$ \\
\hline & $\mathrm{L} 3$ & 16.6 & 6.3 & - & - & 0.02 & $0.94^{(6)}$ \\
\hline \multirow{3}{*}{ E-cane (II) } & L1 & 136.8 & 12.4 & - & 4.78 & 6.96 & $7.24^{(6)}$ \\
\hline & L2 & 7.0 & 1.6 & - & 0.23 & 0.13 & $0.67^{(6)}$ \\
\hline & L3 & 19.0 & 4.6 & - & 0.31 & 0.31 & $1.24^{(6)}$ \\
\hline \multirow{3}{*}{ S-cane } & $\mathrm{L} 1$ & 214.4 & 40.4 & - & 11.47 & - & $18.55^{(6)}$ \\
\hline & L2 & 9.5 & 1.1 & - & 0.39 & - & $0.90^{(6)}$ \\
\hline & L3 & 23.6 & 6.3 & - & 1.14 & - & $2.10^{(6)}$ \\
\hline
\end{tabular}

Note:

(1) TS: total solids; (2) TSS: total suspended solid; (3) EC: electrolytic conductivity; (4) chemical oxygen demand; (5) unfiltered samples were used for COD measurements; (6) filtered samples used for COD measurement; "-" data is not available. 
Table 6 Elemental analyses (mg/L) of liquid by-products L1, L2 and L3 from processing green banagrass (BanaP276 and G-Bana), purple banagrass (P-Bana), guinea grass (OG03), and energy cane (E-cane) using ISE and ICP-AES.

\begin{tabular}{|c|c|c|c|c|c|c|c|}
\hline Sample ID & & $\mathrm{K}^{+}$ & $\mathrm{Na}^{+}$ & $\mathrm{Ca}^{2+}$ & $\mathrm{Mg}^{2+}$ & $\mathrm{Ca}^{2+}+\mathrm{Mg}^{2+}$ & $\mathrm{Cl}^{-}$ \\
\hline Tap water & & $2.4(3.1)$ & $46(51)$ & $7.5(9)$ & (12) & 15.4 & 0.6 \\
\hline \multirow{3}{*}{ Bana-P0 } & L1 & 8039 & 265 & 105 & - & 454 & 8598 \\
\hline & L2 & 572 & 60 & 16 & - & 106 & 566 \\
\hline & L3 & 726 & 63 & 13 & - & 87 & 731 \\
\hline \multirow{3}{*}{ Bana-P138 } & $\mathrm{L} 1$ & 8751 & 183 & 37 & - & 319 & 8988 \\
\hline & L2 & 556 & 53 & 9 & - & 75 & 463 \\
\hline & L3 & 878 & 59 & 8 & - & 84 & 708 \\
\hline \multirow{3}{*}{ Bana-P276 } & L1 & $8270(9100)$ & $216(246)$ & 148 (215) & (918) & 378 & 9404 \\
\hline & $\mathrm{L} 2$ & 419 (457) & $52(59)$ & $20(18)$ & (47) & 102 & 578 \\
\hline & L3 & 899 (1000) & $65(72)$ & $2(67)$ & (109) & 146 & 763 \\
\hline \multirow{3}{*}{ Bana-P414 } & L1 & 9272 & 260 & 31 & - & 386 & 14007 \\
\hline & L2 & 427 & 51 & 8 & - & 78 & 336 \\
\hline & L3 & 841 & 60 & 6 & - & 94 & 650 \\
\hline \multirow{3}{*}{ P-Bana } & $\mathrm{L} 1$ & 8022 & 272 & 283 & (1044) & - & 8250 \\
\hline & L2 & 941 & 85 & 114 & (157) & - & 4870 \\
\hline & L3 & 551 & 72 & 15 & (75) & - & 830 \\
\hline \multirow{3}{*}{ G-Bana } & L1 & 8779 & 260 & 621 & (1687) & - & 6240 \\
\hline & L2 & 1187 & 85 & 171 & (246) & - & 3760 \\
\hline & L3 & 646 & 70 & 21 & (88) & - & 660 \\
\hline \multirow{3}{*}{ OG03 } & L1 & 9878 & 2044 & 409 & (2430) & - & 8590 \\
\hline & L2 & 1028 & 250 & 122 & (285) & - & 6460 \\
\hline & L3 & 713 & 190 & 18 & (136) & - & 860 \\
\hline \multirow{3}{*}{ E-cane } & $\mathrm{L} 1$ & $\begin{array}{r}1890 \pm 349 \\
(2980 \pm 477)\end{array}$ & $\begin{array}{l}338 \pm 55 \\
(95 \pm 37)\end{array}$ & $\begin{array}{c}1051 \pm 417 \\
(795 \pm 227)\end{array}$ & $(722 \pm 121)$ & $1997 \pm 1619$ & $1690 \pm 211$ \\
\hline & L2 & $\begin{array}{r}167 \pm 15 \\
(196 \pm 11)\end{array}$ & $\begin{array}{r}26 \pm 2 \\
(50 \pm 9)\end{array}$ & $\begin{array}{r}58 \pm 7 \\
(54 \pm 6)\end{array}$ & $(50 \pm 9)$ & $182 \pm 31$ & $192 \pm 28$ \\
\hline & L3 & $\begin{array}{r}388 \pm 9 \\
(413 \pm 7)\end{array}$ & $\begin{array}{r}24 \pm 4 \\
(52 \pm 5)\end{array}$ & $\begin{array}{r}101 \pm 2 \\
(123 \pm 2)\end{array}$ & $(52 \pm 5)$ & $163 \pm 17$ & $306 \pm 10$ \\
\hline \multirow{3}{*}{ P-Bana (II) } & L1 & 5723 & 1565 & 144 & - & 898 & 3281 \\
\hline & $\mathrm{L} 2$ & 835 & 82 & 5 & - & 53 & 398 \\
\hline & L3 & 1522 & 95 & 4 & - & 52 & 579 \\
\hline \multirow{3}{*}{ E-cane (II) } & L1 & 3527 & 653 & 637 & - & 1758 & 2329 \\
\hline & L2 & 483 & 50 & 42 & - & 83 & 233 \\
\hline & L3 & 499 & 63 & 71 & - & 209 & 305 \\
\hline \multirow{3}{*}{ S-cane } & $\mathrm{L} 1$ & 1442 & 340 & 410 & - & 2533 & 1197 \\
\hline & L2 & 215 & 28 & 27 & - & 99 & 134 \\
\hline & L3 & 435 & 36 & 40 & - & 190 & 187 \\
\hline
\end{tabular}

Note: "_" data is not available. ICP-AES measurements present in parentheses 


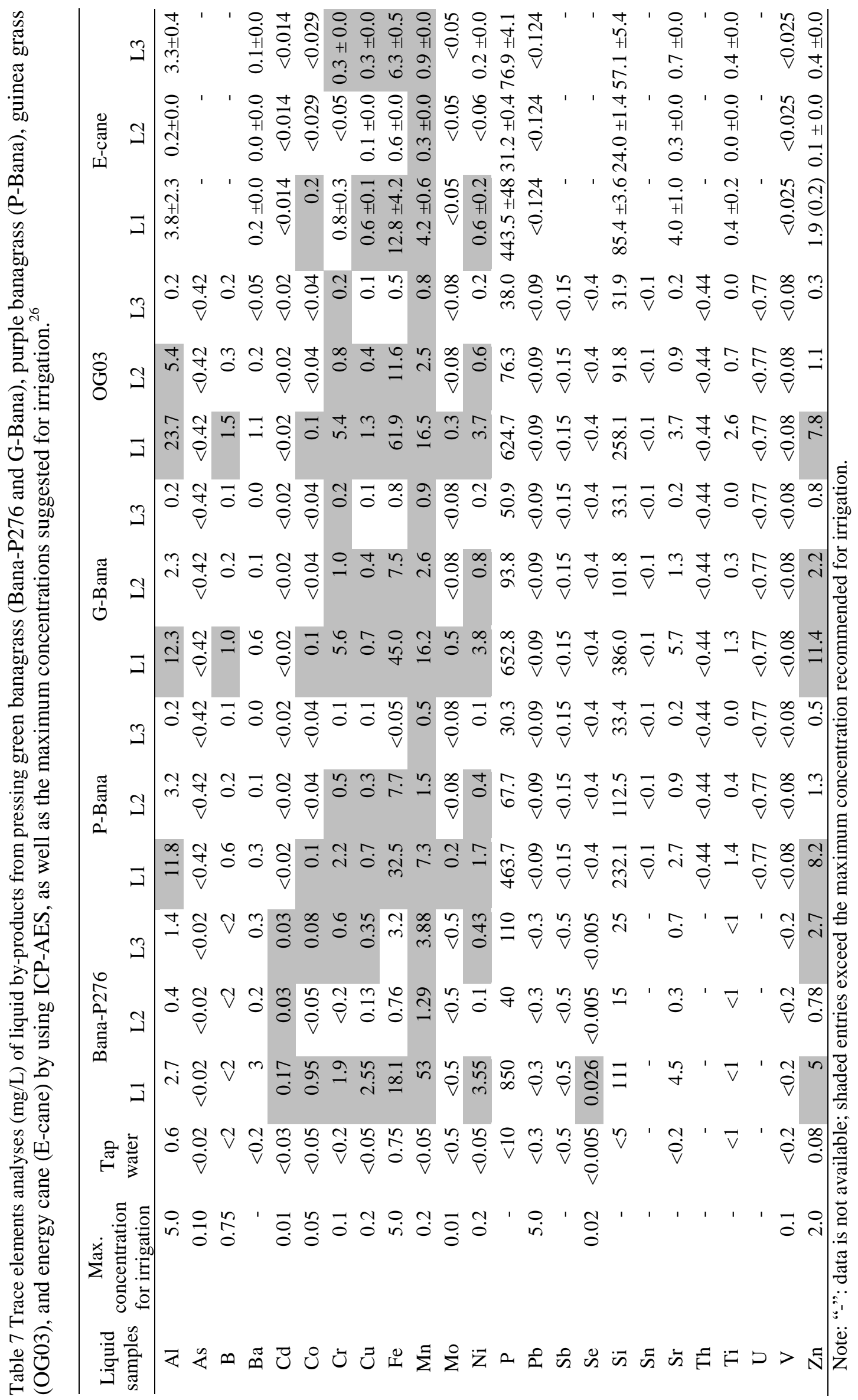


Table 8 S0 moisture content and first liquid removal efficiency for samples using a screw press with an effective exit cone pressure of $70 \mathrm{kPa}$

\begin{tabular}{lccccccc}
\hline Biomass samples & G-Bana & P-Bana & OG03 & E-cane & P-Bana (II) & E-cane (II) & S-cane \\
\hline $\begin{array}{l}\text { S0 moisture content, } \\
\% \text { (wet basis) }\end{array}$ & 57.7 & 65 & 56.9 & 67.3 & $66.8 \pm 0.1$ & $69.4 \pm 0.6$ & $69.1 \pm 1.6$ \\
$\begin{array}{l}\text { Liquid yield from first pressing, } \\
\text { (L1 as \% of S0 (wet basis) }\end{array}$ & 20.0 & 29.7 & 16.7 & 51.4 & 38.4 & 53.0 & 60.6 \\
\hline
\end{tabular}


Table 9 Summary of liquid yields, material and element mass balances, and ash and element removal efficiency test results for increasing screw press outlet pressures for green banagrass (Bana) using the process shown in Figure 1.

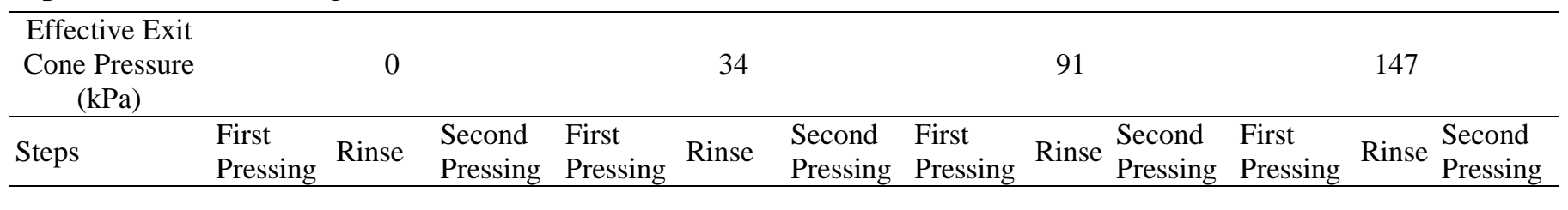

Liquid yield (mass \% of S0 moisture $16.1-{ }^{\mathrm{h}} \quad 25$.

$25.1 \quad-{ }^{\mathrm{h}} \quad 24.4$

$-$

26.4

removed as L1)

Material and elements mass balance (mass fraction)

$\begin{array}{llllllllll}\text { Material } & 0.97^{\mathrm{a}} & 1.00^{\mathrm{b}} 0.98^{\mathrm{c}} & 0.94^{\mathrm{a}} & 1.00^{\mathrm{b}} 0.98^{\mathrm{c}} & 0.98^{\mathrm{a}} & 1.00^{\mathrm{b}} 0.98^{\mathrm{c}} & 0.92^{\mathrm{a}} & 1.00^{\mathrm{b}} & 0.99^{\mathrm{c}} \\ \mathrm{K} & 1.17^{\mathrm{d}} & 1.04^{\mathrm{e}} & 1.28^{\mathrm{d}} & 1.19^{\mathrm{e}} & 1.24^{\mathrm{d}} & 1.08^{\mathrm{e}} & & 1.28^{\mathrm{d}} & 1.09^{\mathrm{e}} \\ \mathrm{Na} & 1.24^{\mathrm{d}} & 0.96^{\mathrm{e}} & 1.23^{\mathrm{d}} & 0.82^{\mathrm{e}} & 1.06^{\mathrm{d}} & 0.99^{\mathrm{e}} & & 1.33^{\mathrm{d}} & 0.87^{\mathrm{e}} \\ \mathrm{Ca} & 0.89^{\mathrm{d}} & 0.81^{\mathrm{e}} & 0.74^{\mathrm{d}} & 0.76^{\mathrm{e}} & 0.91^{\mathrm{d}} & 0.85^{\mathrm{e}} & 0.91^{\mathrm{d}} & 0.73^{\mathrm{e}} \\ \mathrm{Cl} & 1.33^{\mathrm{d}} & 1.40^{\mathrm{e}} & 1.49^{\mathrm{d}} & 1.38^{\mathrm{e}} & 1.48^{\mathrm{d}} & 1.81^{\mathrm{e}} & 1.88^{\mathrm{d}} & 1.37^{\mathrm{e}}\end{array}$

Ash and elements removal efficiency (\%)

\begin{tabular}{lcccccccc} 
Ash & $9.4^{\mathrm{f}}$ & $73.1^{\mathrm{g}}$ & $24.7^{\mathrm{f}}$ & $69.8^{\mathrm{g}}$ & $16.0^{\mathrm{f}}$ & $65.8^{\mathrm{g}}$ & $13.9^{\mathrm{f}}$ & $69.7^{\mathrm{g}}$ \\
$\mathrm{K}$ & $14.3^{\mathrm{f}}$ & $81.4^{\mathrm{g}}$ & $25.9^{\mathrm{f}}$ & $71.6^{\mathrm{g}}$ & $24.8^{\mathrm{f}}$ & $74.1^{\mathrm{g}}$ & $31.7^{\mathrm{f}}$ & $79.4^{\mathrm{g}}$ \\
$\mathrm{Na}$ & $3.1^{\mathrm{f}}$ & $54.9^{\mathrm{g}}$ & $4.0^{\mathrm{f}}$ & $62.5^{\mathrm{g}}$ & $27.6^{\mathrm{f}}$ & $39.3^{\mathrm{g}}$ & $10.0^{\mathrm{f}}$ & $54.7^{\mathrm{g}}$ \\
$\mathrm{Ca}$ & $13.3^{\mathrm{f}}$ & $25.8^{\mathrm{g}}$ & $27.1^{\mathrm{f}}$ & $26.7^{\mathrm{g}}$ & $13.6^{\mathrm{f}}$ & $25.0^{\mathrm{g}}$ & $10.0^{\mathrm{f}}$ & $28.5^{\mathrm{g}}$ \\
$\mathrm{Cl}$ & $16.8^{\mathrm{f}}$ & $88.2^{\mathrm{g}}$ & $31.7^{\mathrm{f}}$ & $80.7^{\mathrm{g}}$ & $33.4^{\mathrm{f}}$ & $79.5^{\mathrm{g}}$ & $44.2^{\mathrm{f}}$ & $87.7^{\mathrm{g}}$ \\
\hline
\end{tabular}

Note:

${ }^{\mathrm{a}}=\frac{m_{S 1}+m_{L 1}}{m_{S 0}}$, where $m$ is mass;

$\mathrm{b}=\frac{m_{S 2}+m_{L 2}}{m_{S 1}+m_{\text {tapwater }}}$, where $m$ is mass;

${ }^{c}=\frac{m_{S 3}+m_{L 3}}{m_{S 2}}$, where $m$ is mass;

$\mathrm{d}=\frac{m_{i, S 1}+m_{i, L 1}}{m_{i, S 0}}$, where $m$ is mass and $i=\mathrm{K}, \mathrm{Na}, \mathrm{Ca}$, or $\mathrm{Cl}$;

$\mathrm{e}=\frac{m_{i, S 3}+m_{i, L 3}+m_{i, L 2}}{m_{i, S 1}+m_{i, \text { tapwater }}}$, where $m$ is mass and $i=\mathrm{K}, \mathrm{Na}, \mathrm{Ca}$, or $\mathrm{Cl}$;

$\mathrm{f}=100 \times \frac{m_{i, S 0}-m_{i, S 1}}{m_{i, S 0}}$, where $m$ is mass and $i=$ ash, $\mathrm{K}, \mathrm{Na}, \mathrm{Ca}$, or $\mathrm{Cl}$;

$\mathrm{g}=100 \times \frac{m_{i, S 1}-m_{i, S 3}}{m_{i, S 1}}$, where $m$ is mass and $i=$ ash, $\mathrm{K}, \mathrm{Na}, \mathrm{Ca}$, or $\mathrm{Cl}$;

h - indicates that data is not available. 
Table 10 Summary of test results for G-Bana. P-Bana, OG03, and E-cane with an effective screw press exit pressure of 72 kPa using the process shown in Figure 1.

\begin{tabular}{|c|c|c|c|c|c|c|c|c|c|c|c|}
\hline Samples & G-Bana & & F & -Bana & & & OG03 & & & -cane & \\
\hline Steps & $\begin{array}{cc}\text { First } \\
\text { Pressing }\end{array}$ & $\begin{array}{c}\text { Second } \\
\text { Pressing }\end{array}$ & $\begin{array}{c}\text { First } \\
\text { Pressing }\end{array}$ & Rinse & $\begin{array}{c}\text { Second } \\
\text { pressing }\end{array}$ & $\begin{array}{c}\text { First } \\
\text { Pressing }\end{array}$ & Rinse & $\begin{array}{l}\text { Second } \\
\text { Pressing }\end{array}$ & $\begin{array}{c}\text { First } \\
\text { Pressing }\end{array}$ & Rinse & $\begin{array}{l}\text { Second } \\
\text { Pressing }\end{array}$ \\
\hline
\end{tabular}

Material and elements mass balance (mass fraction)

\begin{tabular}{|c|c|c|c|c|c|c|c|c|}
\hline Material & $0.953^{\mathrm{a}}$ & $0.867^{\mathrm{c}}$ & $0.995^{\mathrm{a}}$ & $0.99^{\mathrm{b}}$ & $0.913^{\mathrm{a}}$ & $0.995^{\mathrm{c}}$ & $0.98 \pm 0.03^{\mathrm{a}}$ & $0.98 \pm 0.02^{\mathrm{c}}$ \\
\hline $\mathrm{K}$ & $1.08^{\mathrm{d}}$ & $-{ }^{\mathrm{h}}$ & $0.95^{\mathrm{d}}$ & $-{ }^{h}$ & $0.95^{\mathrm{d}}$ & $-{ }^{h}$ & $1.04 \pm 0.06^{\mathrm{d}}$ & $1.04 \pm 0.05^{\mathrm{c}}$ \\
\hline $\mathrm{Na}$ & $0.73^{\mathrm{d}}$ & $-{ }^{h}$ & $0.90^{\mathrm{d}}$ & $-{ }^{h}$ & $1.23^{\mathrm{d}}$ & $-{ }^{\mathrm{h}}$ & $0.98 \pm 0.03^{\mathrm{d}}$ & $0.94 \pm 0.02^{\mathrm{c}}$ \\
\hline $\mathrm{Ca}$ & $0.86^{\mathrm{d}}$ & $-{ }^{\mathrm{h}}$ & $0.92^{\mathrm{d}}$ & $-{ }^{h}$ & $1.02^{\mathrm{d}}$ & $-{ }^{h}$ & $0.97 \pm 0.02^{\mathrm{d}}$ & $1.07 \pm 0.01^{\mathrm{c}}$ \\
\hline $\mathrm{Cl}$ & $-{ }^{h}$ & $-{ }^{h}$ & $-{ }^{h}$ & $-{ }^{h}$ & $-{ }^{h}$ & $-{ }^{\mathrm{h}}$ & $1.03 \pm 0.05^{\mathrm{d}}$ & $1.26 \pm 0.09^{\mathrm{c}}$ \\
\hline \multicolumn{9}{|c|}{ Ash and elements removal efficiency (\%) } \\
\hline Ash & $22.0^{\mathrm{f}}$ & $67.8^{\mathrm{g}}$ & $28.1^{\mathrm{f}}$ & $63.1^{\mathrm{g}}$ & $14.3^{\mathrm{f}}$ & $70.3^{\mathrm{g}}$ & $35.3 \pm 3.83^{\mathrm{f}}$ & $57.7 \pm 1.88^{\mathrm{g}}$ \\
\hline $\mathrm{K}$ & $30.7^{\mathrm{f}}$ & $91.4^{\mathrm{g}}$ & $56.4^{\mathrm{f}}$ & $73.9^{\mathrm{g}}$ & $33.3^{\mathrm{f}}$ & $84.2^{\mathrm{g}}$ & $62.5 \pm 2.22^{\mathrm{f}}$ & $76.9 \pm 1.03^{\mathrm{g}}$ \\
\hline $\mathrm{Na}$ & $48.5^{\mathrm{f}}$ & $78.7^{\mathrm{g}}$ & $45.9^{\mathrm{f}}$ & $51.4^{\mathrm{g}}$ & $16.6^{\mathrm{f}}$ & $81.3^{\mathrm{g}}$ & $50.5 \pm 2.93^{\mathrm{f}}$ & $45.6 \pm 2.42^{\mathrm{g}}$ \\
\hline $\mathrm{Ca}$ & $26.2^{f}$ & $58.3^{\mathrm{g}}$ & $18.6^{\mathrm{f}}$ & $21.7^{\mathrm{g}}$ & $5.5^{\mathrm{f}}$ & $24.2^{\mathrm{g}}$ & $49.4 \pm 2.99$ & $32.5 \pm 3.00^{\mathrm{g}}$ \\
\hline $\mathrm{Cl}$ & $43.0^{\mathrm{f}}$ & 97.5 & $42.3^{\mathrm{f}}$ & $96.9^{\mathrm{g}}$ & $43.7^{\mathrm{f}}$ & $97.0^{\mathrm{g}}$ & $61.0 \pm 2.31$ & $90.0 \pm 0.44^{\mathrm{g}}$ \\
\hline
\end{tabular}

Note:

$$
\begin{aligned}
\mathrm{a} & =\frac{m_{S 1}+m_{L 1}}{m_{S 0}}, \text { where } m \text { is mass; } \\
\mathrm{b} & =\frac{m_{S 2}+m_{L 2}}{m_{S 1}+m_{\text {tapwater }}}, \text { where } m \text { is mass; } \\
\mathrm{c} & =\frac{m_{S 3}+m_{L 3}}{m_{S 2}}, \text { where } m \text { is mass; } \\
\mathrm{d} & =\frac{m_{i, S 1}+m_{i, L 1}}{m_{i, S 0}}, \text { where } m \text { is mass and } i=\mathrm{K}, \mathrm{Na}, \mathrm{Ca}, \text { or } \mathrm{Cl} ; \\
\mathrm{e} & =\frac{m_{i, S 3}+m_{i, L 3}+m_{i, L 2}}{m_{i, S 1}+m_{i, t a p w a t e r}}, \text { where } m \text { is mass and } i=\mathrm{K}, \mathrm{Na}, \mathrm{Ca}, \text { or } \mathrm{Cl} ; \\
\mathrm{f} & =100 \times \frac{m_{i, S 0}-m_{i, S 1}}{m_{i, S 0}}, \text { where } m \text { is mass and } i=\mathrm{ash}, \mathrm{K}, \mathrm{Na}, \mathrm{Ca}, \text { or } \mathrm{Cl} ; \\
\mathrm{g} & -100 \times \frac{m_{i, S 1}-m_{i, S 3}}{m_{i, S 1}}, \text { where } m \text { is mass and } i=\mathrm{ash}, \mathrm{K}, \mathrm{Na}, \mathrm{Ca}, \text { or } \mathrm{Cl} ; \\
& \text { indicates that data is not available. }
\end{aligned}
$$


Table 11 Mass loss of dry matter in the liquid byproduct streams during fuel processing

\begin{tabular}{cccc}
\hline Sample $^{\mathrm{a}}$ & P-Bana & E-cane & S-cane \\
\hline$\frac{m_{T S, L 1}}{m_{S 0, d r y}}$ & 0.11 & 0.09 & 0.18 \\
$\frac{m_{T S, L 2}}{m_{S 0, d r y}}$ & 0.05 & 0.06 & 0.06 \\
$\frac{m_{T S, L 3}}{m_{S 0, d r y}}$ & 0.02 & 0.05 & 0.06 \\
\hline
\end{tabular}

Note:

${ }^{a} m$ is mass; $T S$ is total solids dry basis; $L 1, L 2$, and $L 3$ indicate liquid streams as shown in Figure $1 ; S O$ is the initial biomass parent material, dry indicates the dry matter fraction of the S0 biomass. 
Figures:

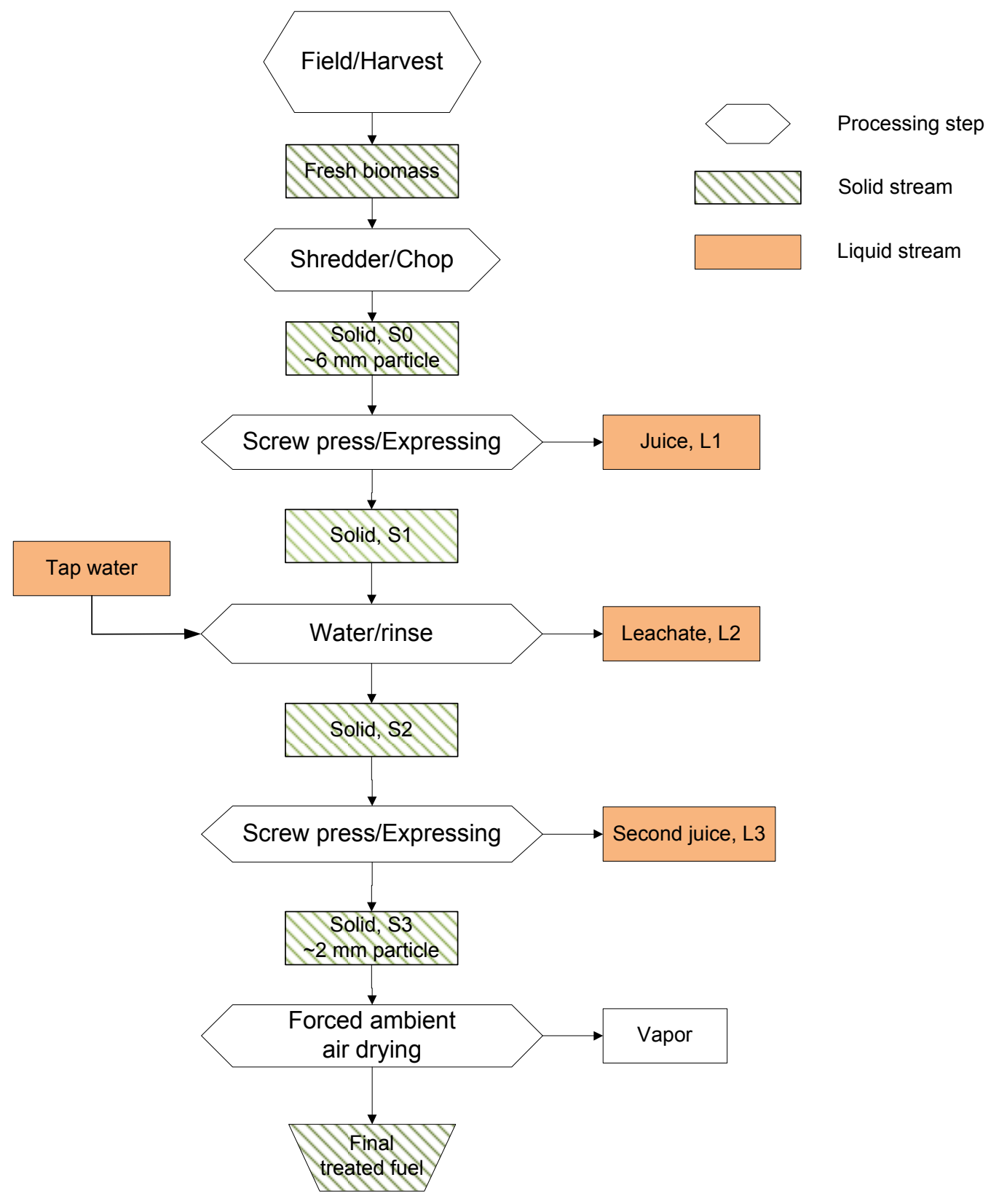

Fig. 1 Schematic of fuel processing and samples generated from banagrass

(Material streams are identified by screw press discharge pressure setting (P\#) and liquid (L\#) or solid (S\#)) 


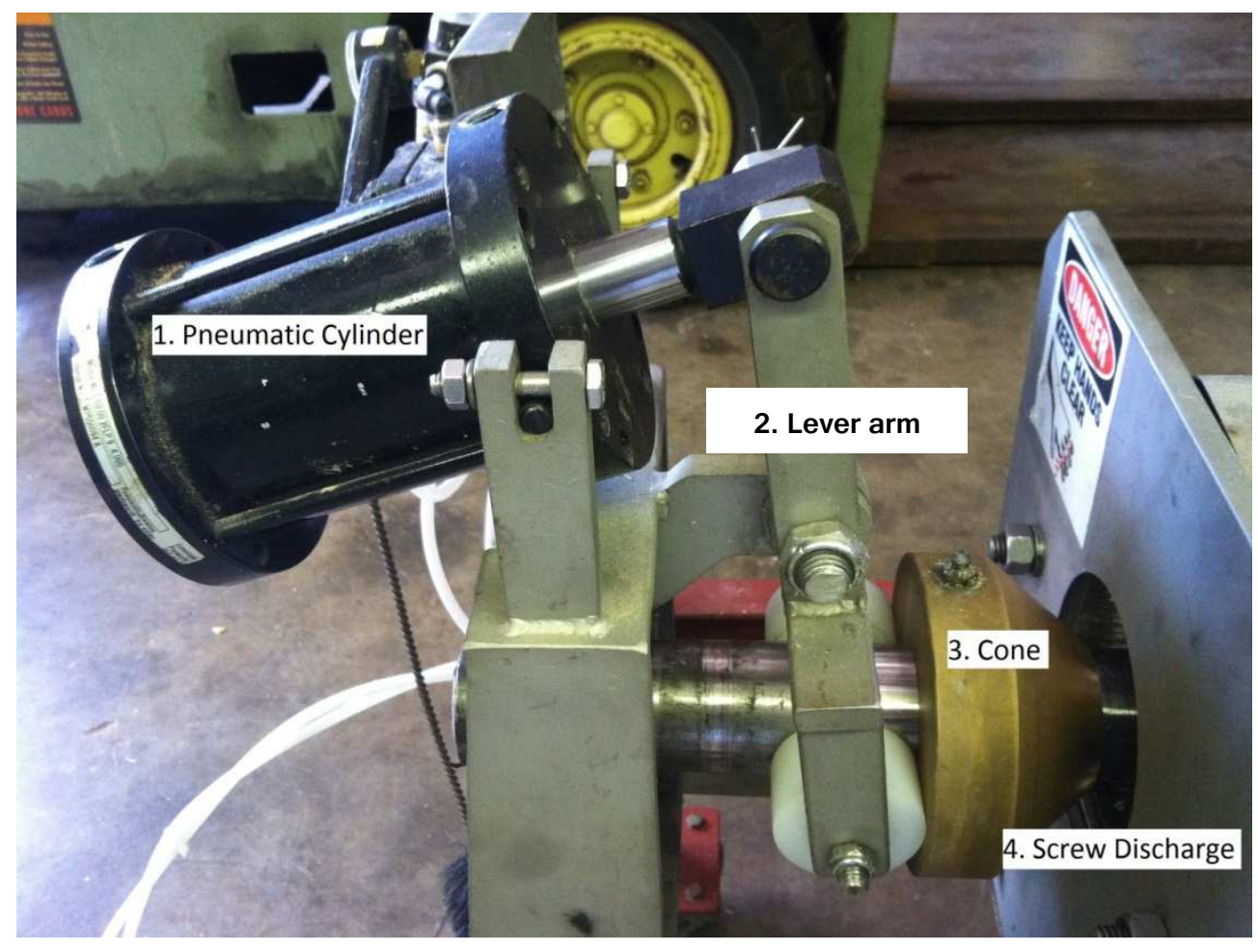

Fig. 2 Pressure discharge system in the compact screw press

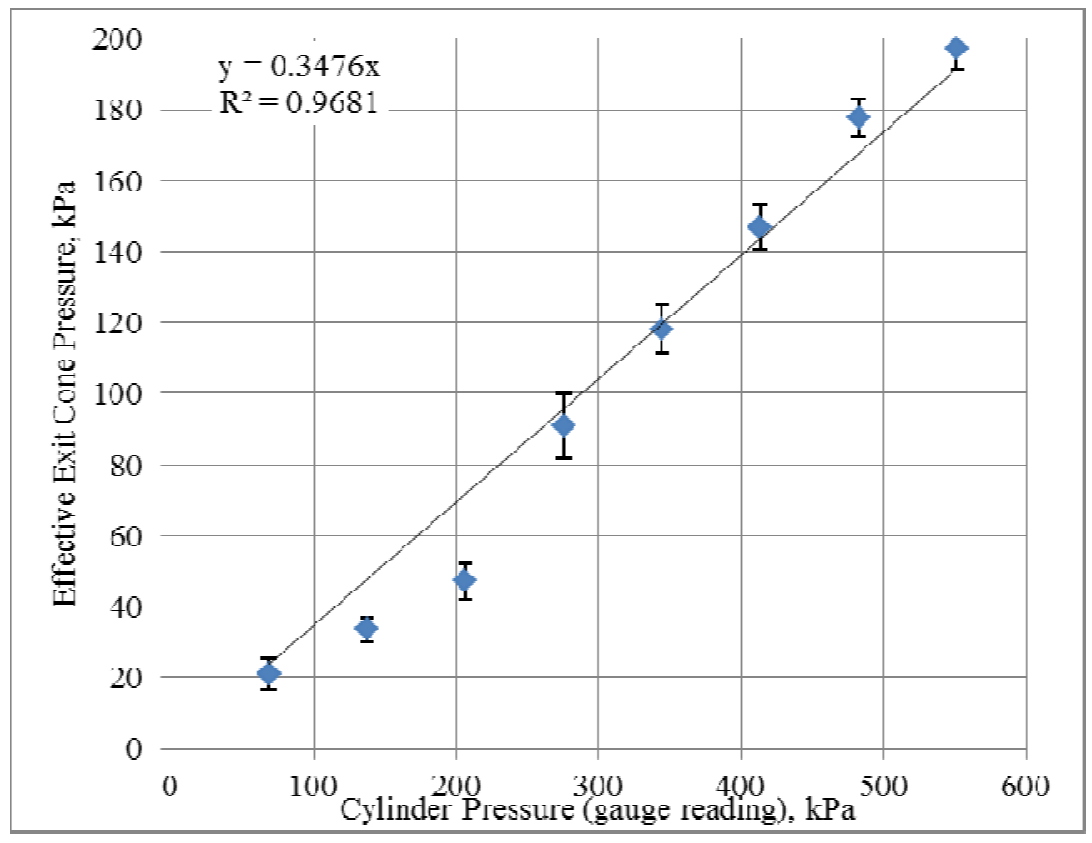

Fig. 3 Effective screw press discharge cone pressure measured as a function of the pneumatic cylinder pressure (gauge reading) setting. Error bars indicate $95 \%$ confidence interval 


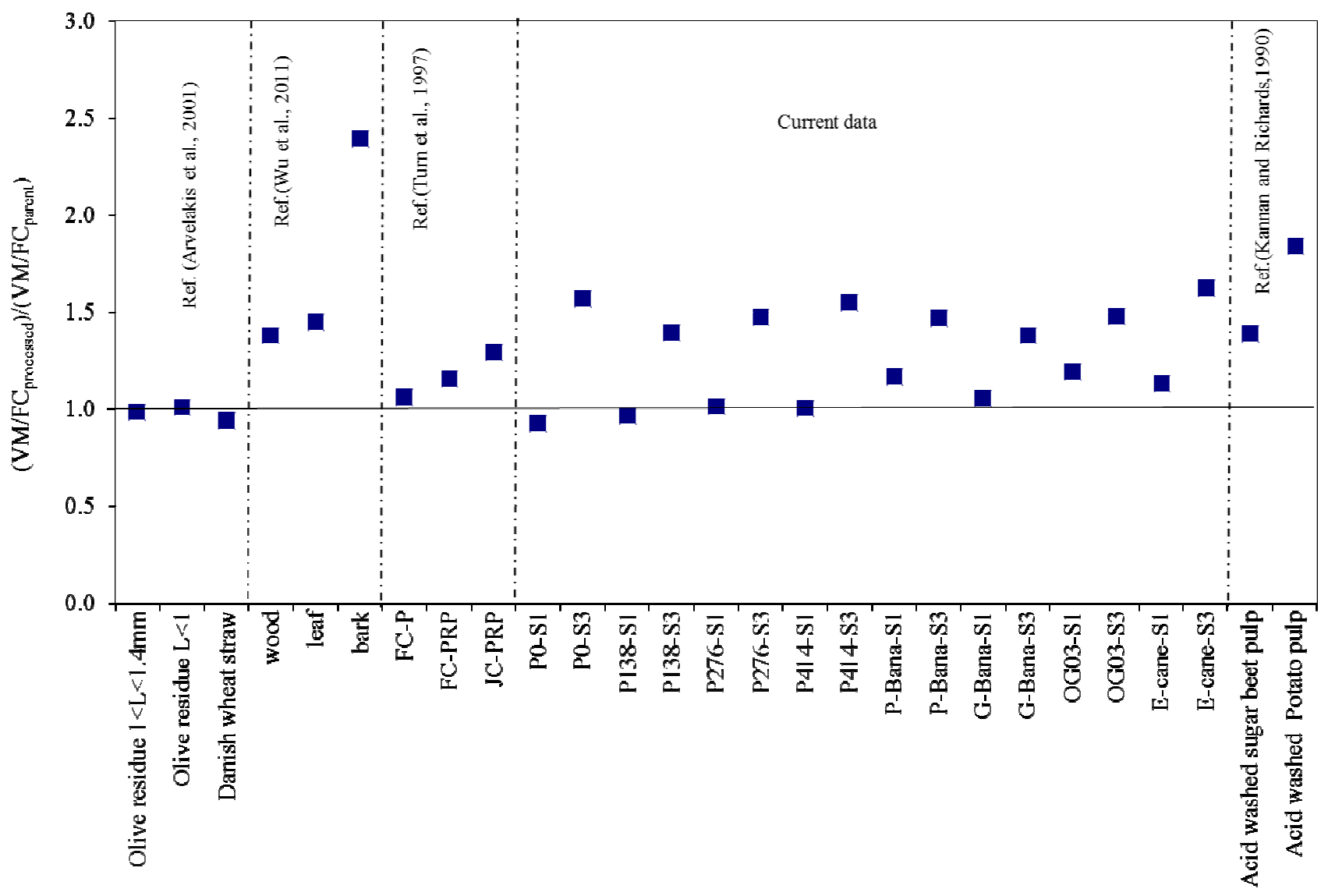

Fig. 4 Comparison of the ratio of the $\mathrm{VM} / \mathrm{FC}$ values for the processed and parent biomass, i.e. $\left(\mathrm{VM} / \mathrm{FC}_{\text {processed }}\right) /\left(\mathrm{VM} / \mathrm{FC}_{\mathrm{S} 0}\right) \quad$ (Note: Literature data were either cited or calculated) 


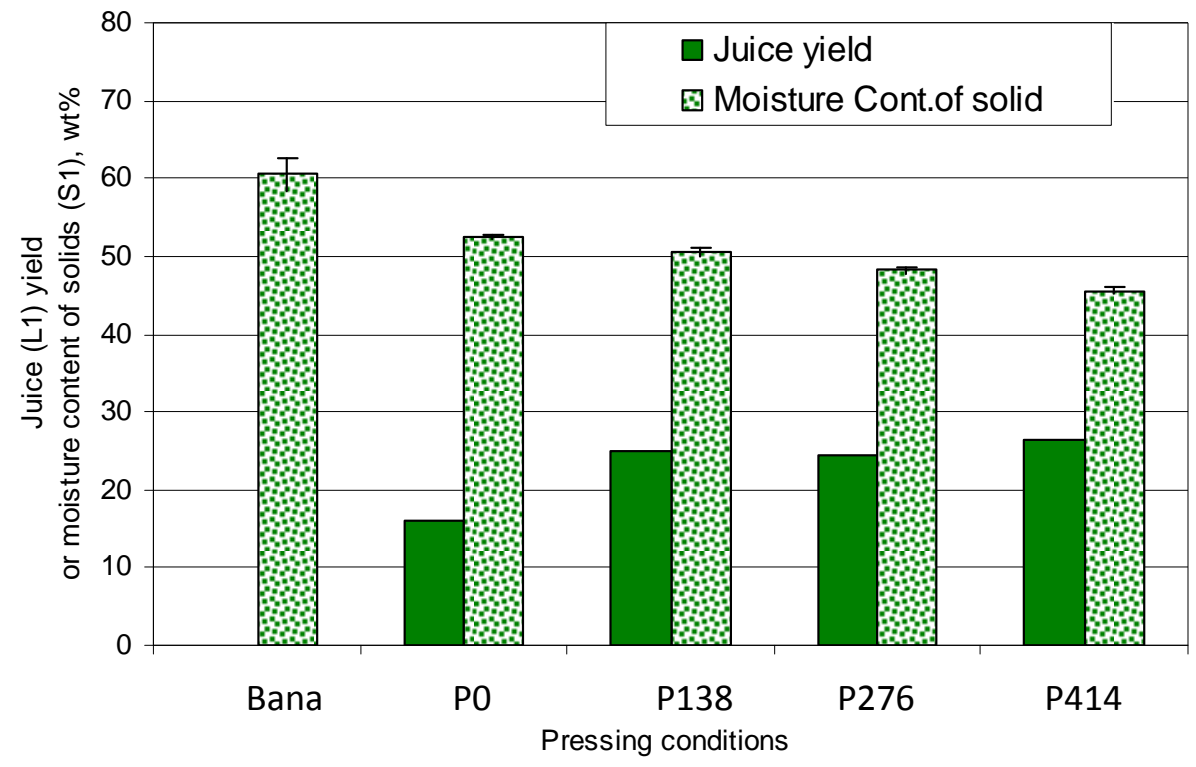

Fig. 5 Liquid yields (based on wet input, S0) and moisture contents (based on wet output, S1) of pressed solid products (Sample: Bana) after the first pressing as a function of screw press exit pressure. 


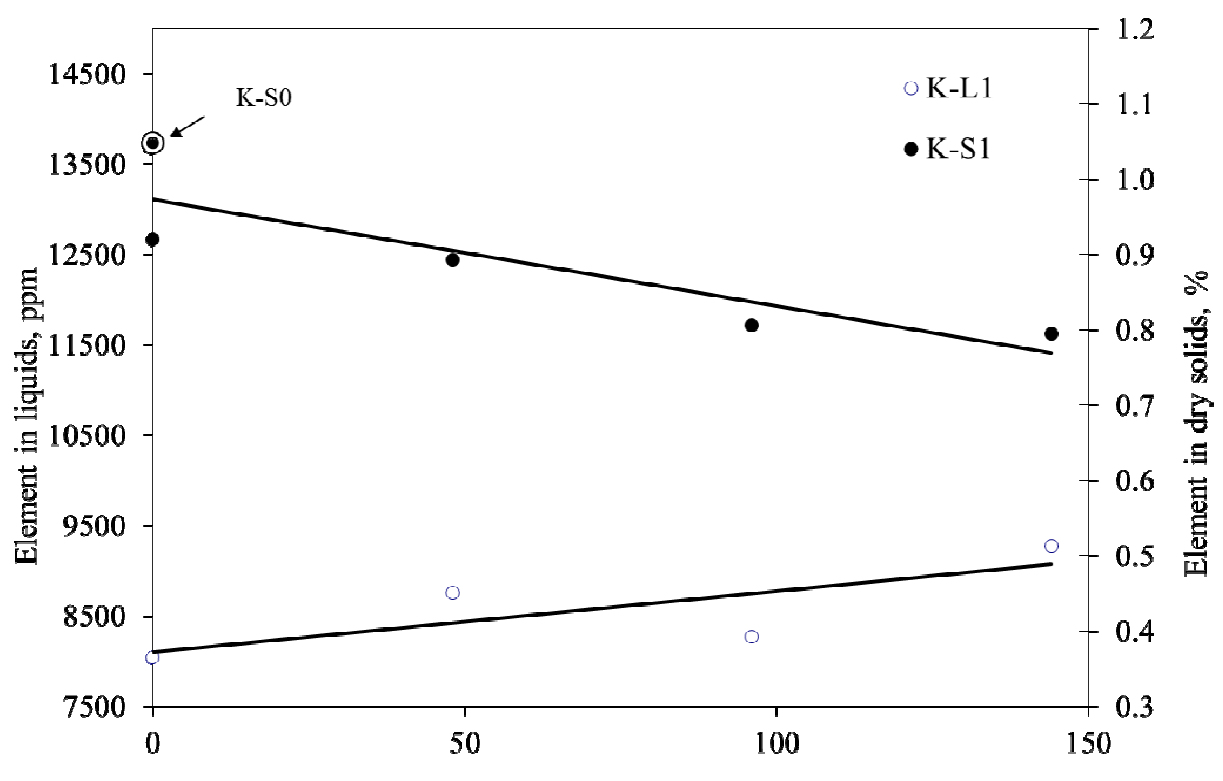

Effective Exit Cone Pressure, KPa

(a)

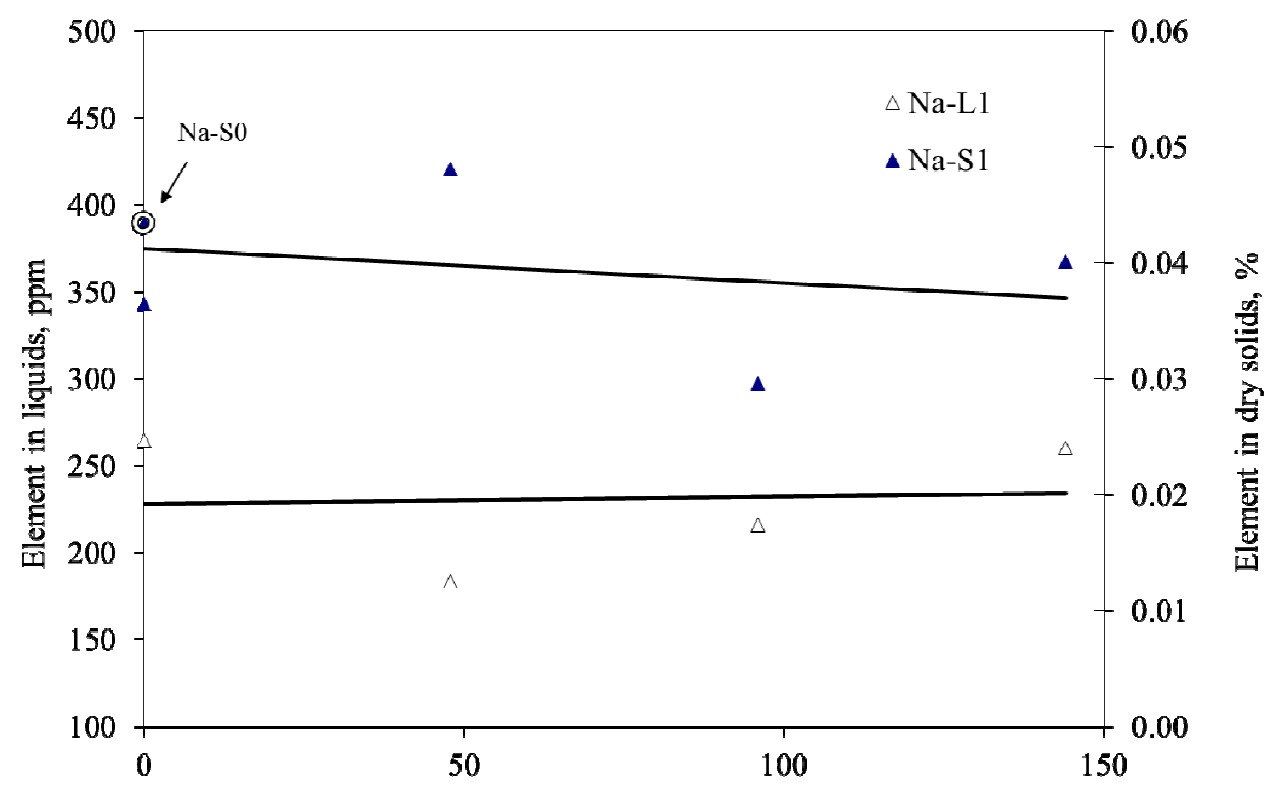

Effective Exit Cone Pressure, KPa

(b) 


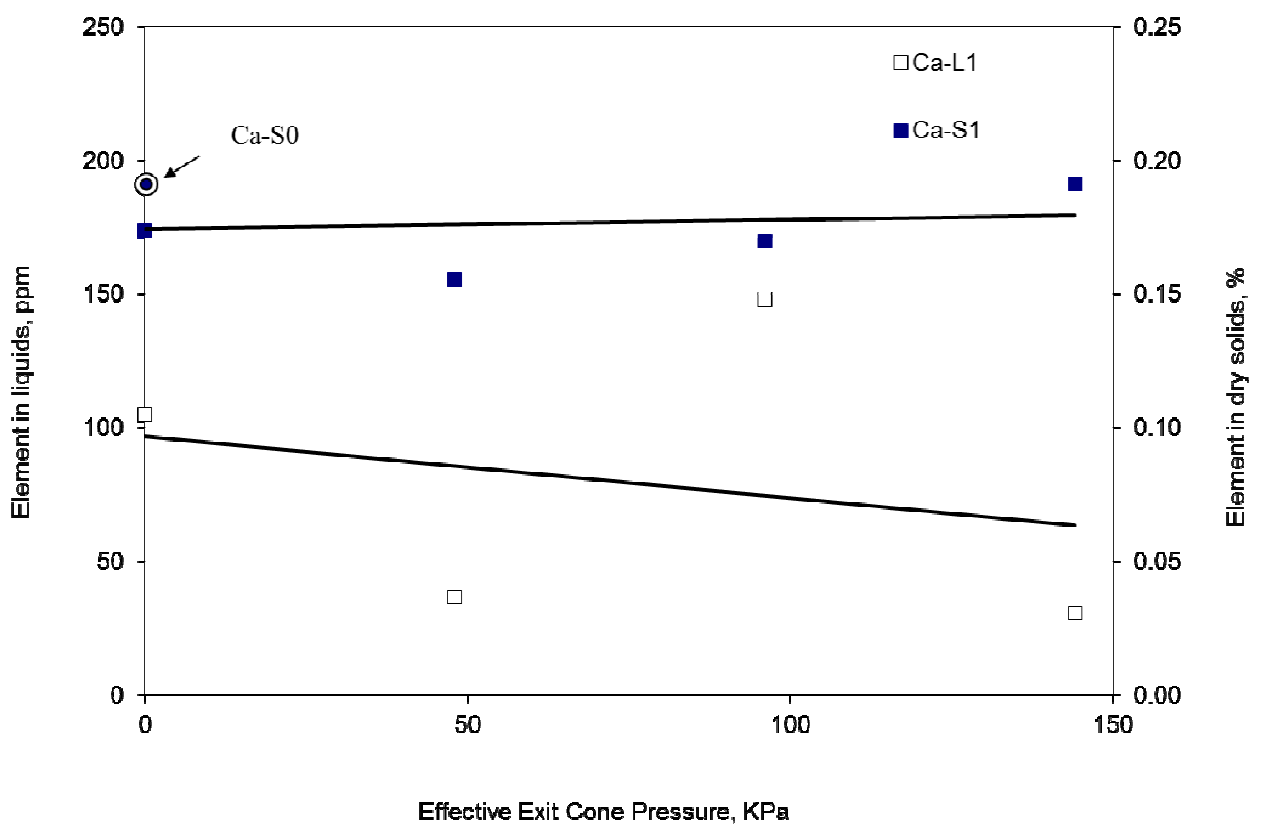

(c)

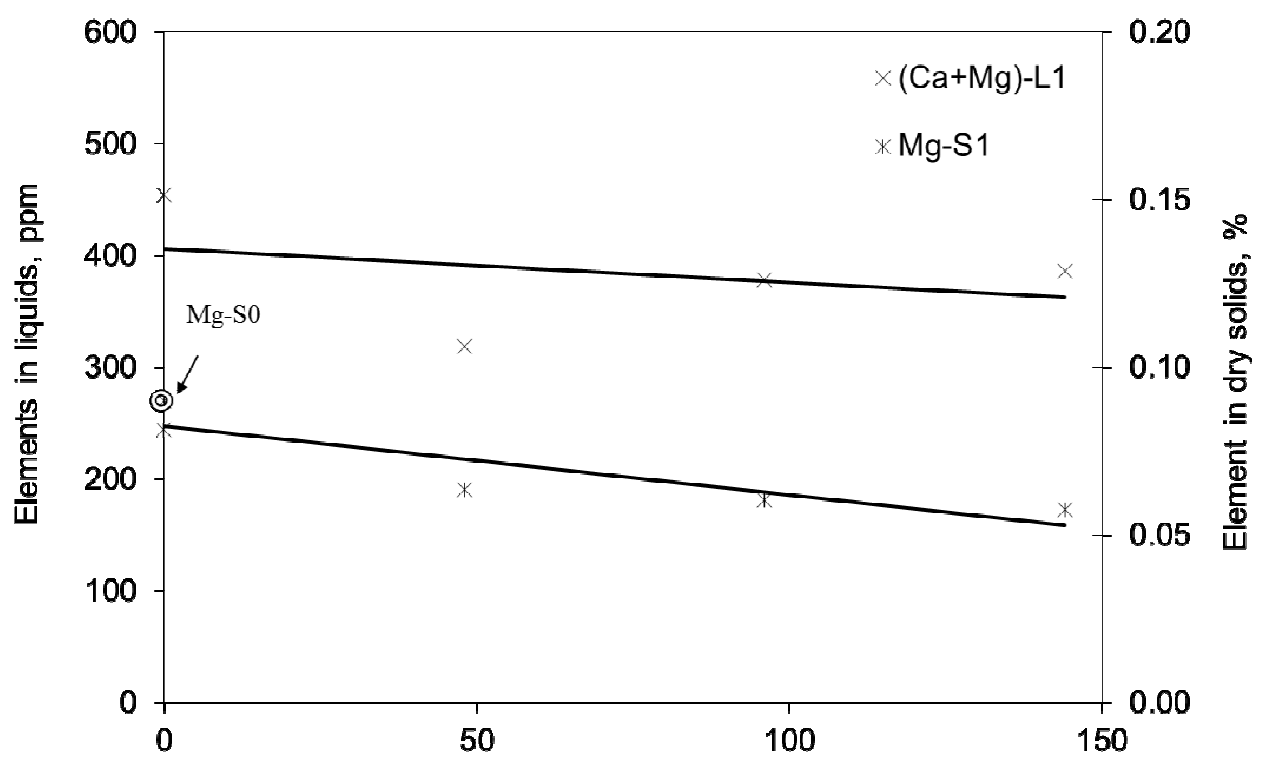

Effective Exit Cone Pressure, KPa

(d) 


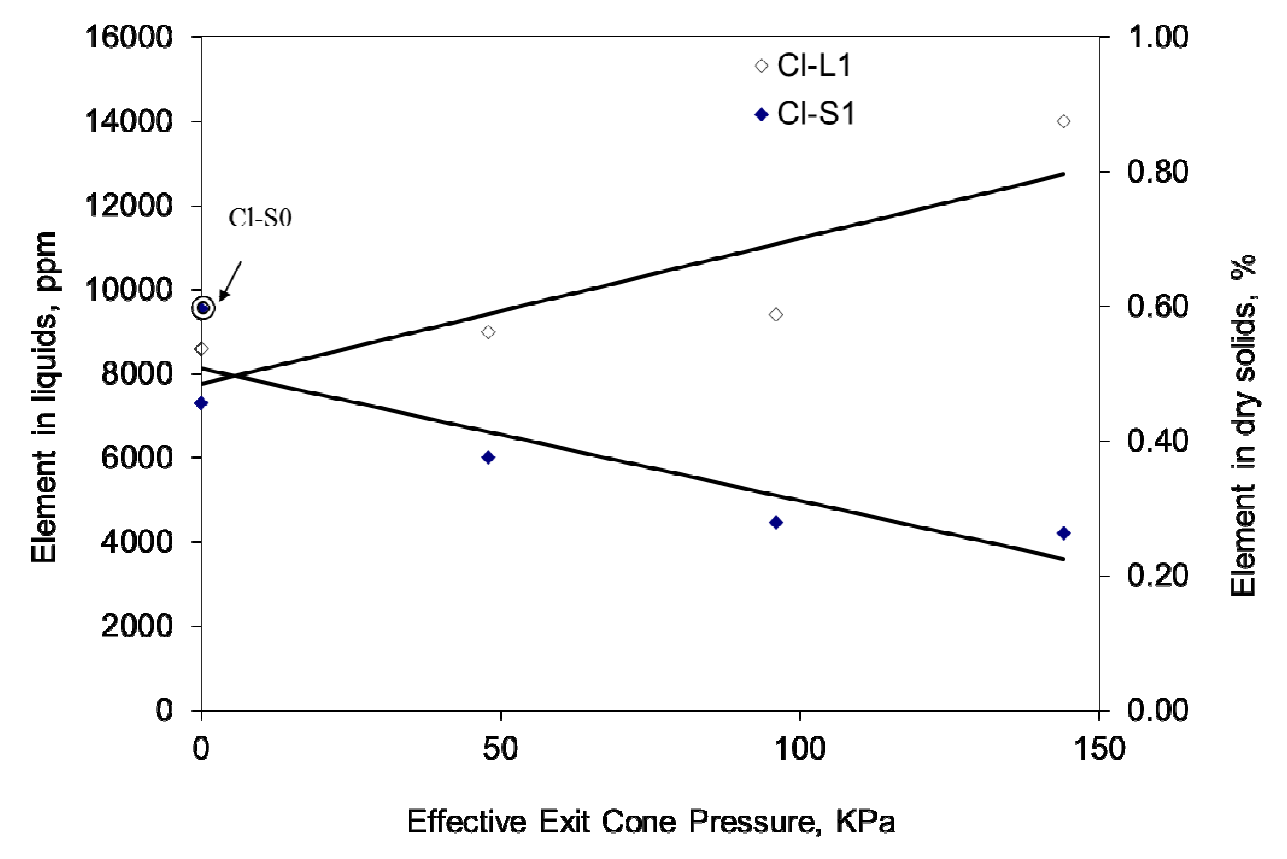

(e)

Fig. 6 Changes of element concentrations in liquid (L1) and solid samples (S1) with varied effective exit cone pressure in the first pressing step (Sample: Bana)

((a) $\mathrm{K}$; (b) $\mathrm{Na}$; (c) $\mathrm{Ca}$; (d) $\mathrm{Mg}$ and $(\mathrm{Ca}+\mathrm{Mg})$; (e) $\mathrm{Cl}$ ) 


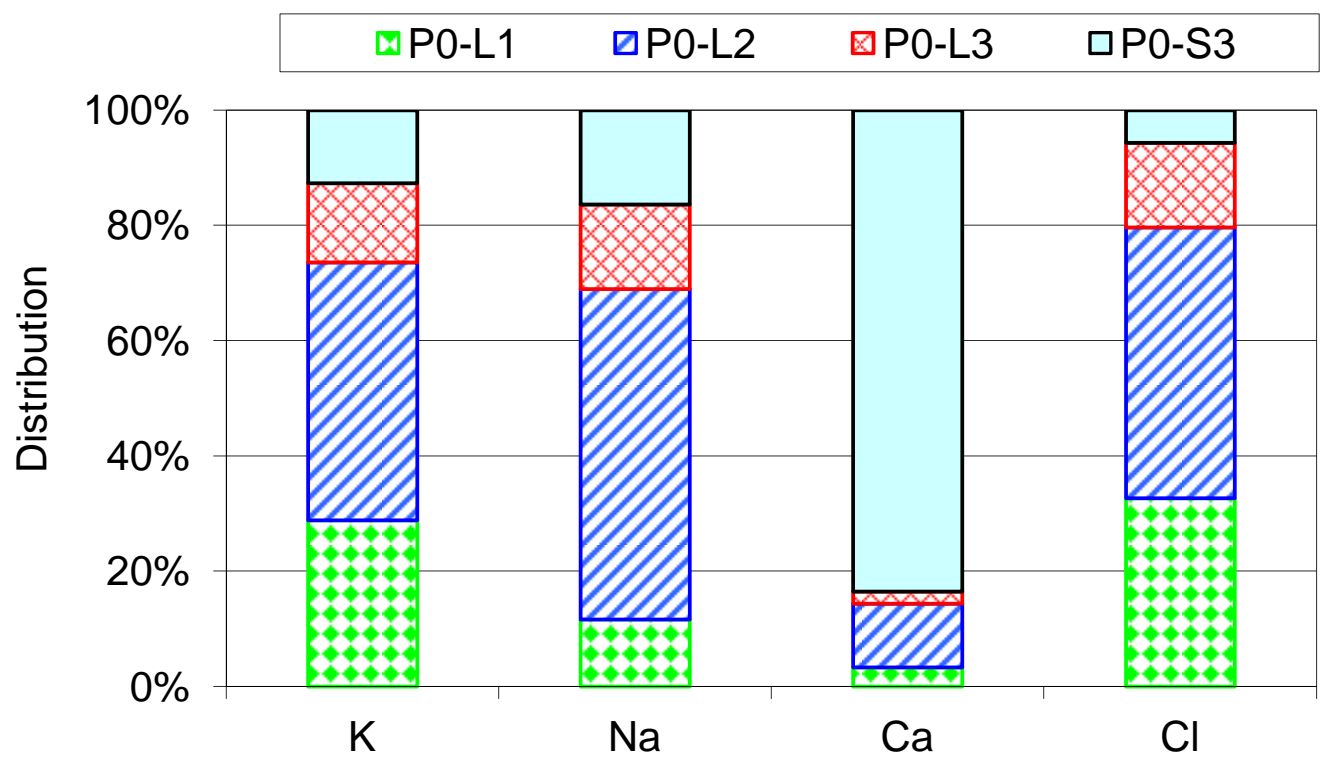

(a)

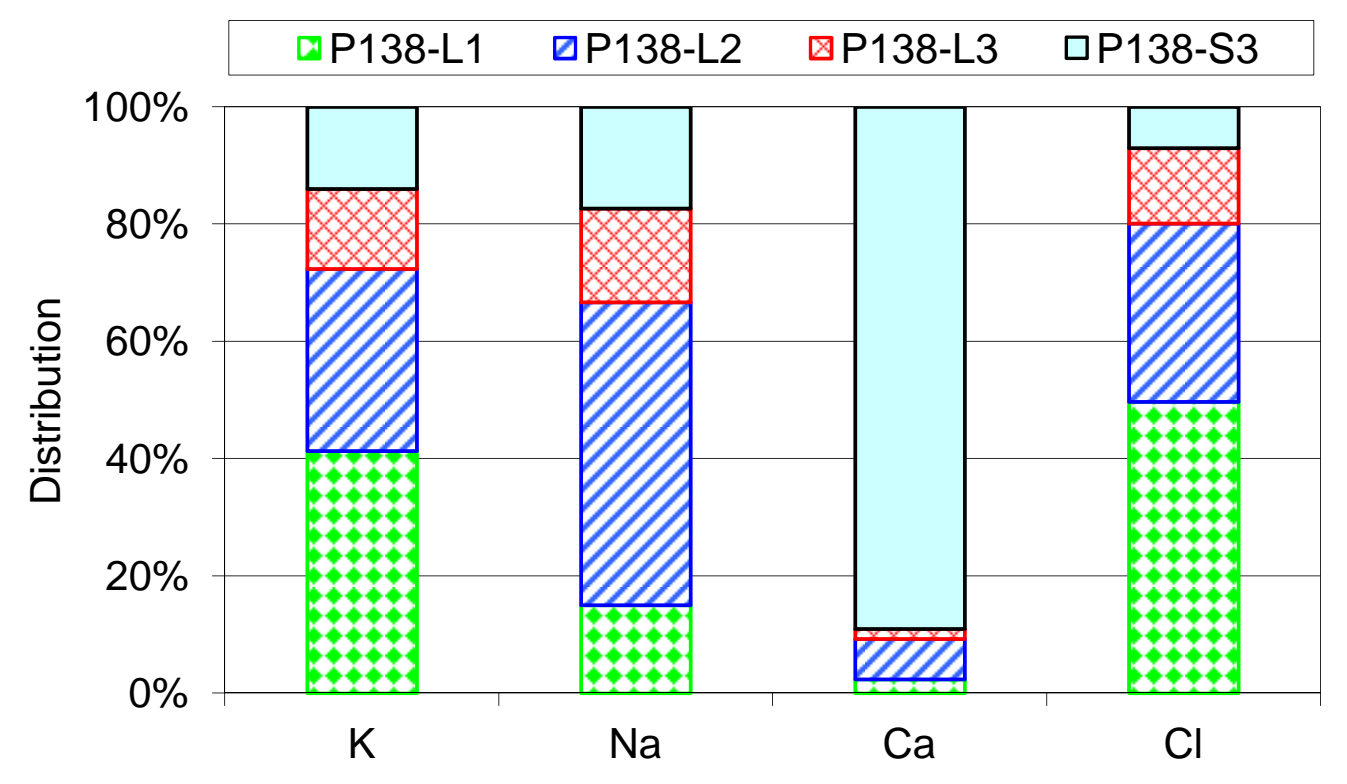

(b) 


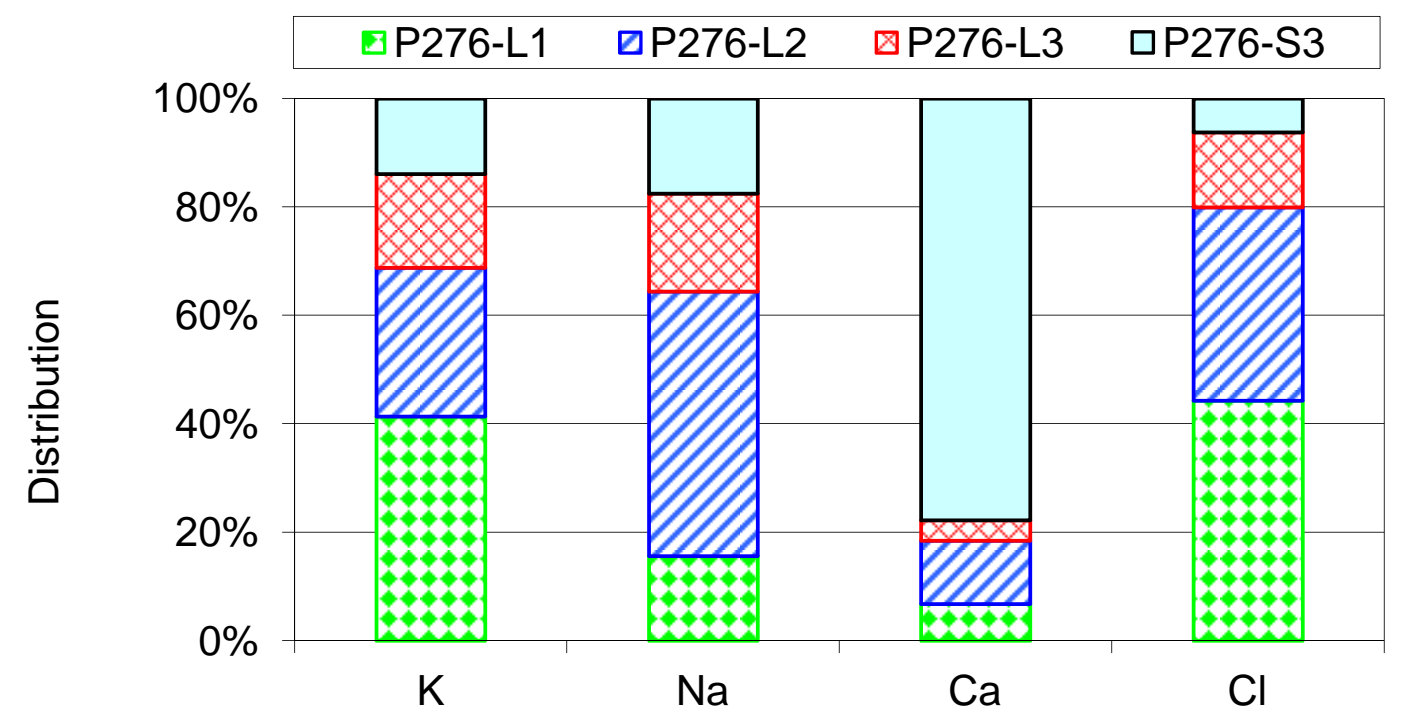

(c)

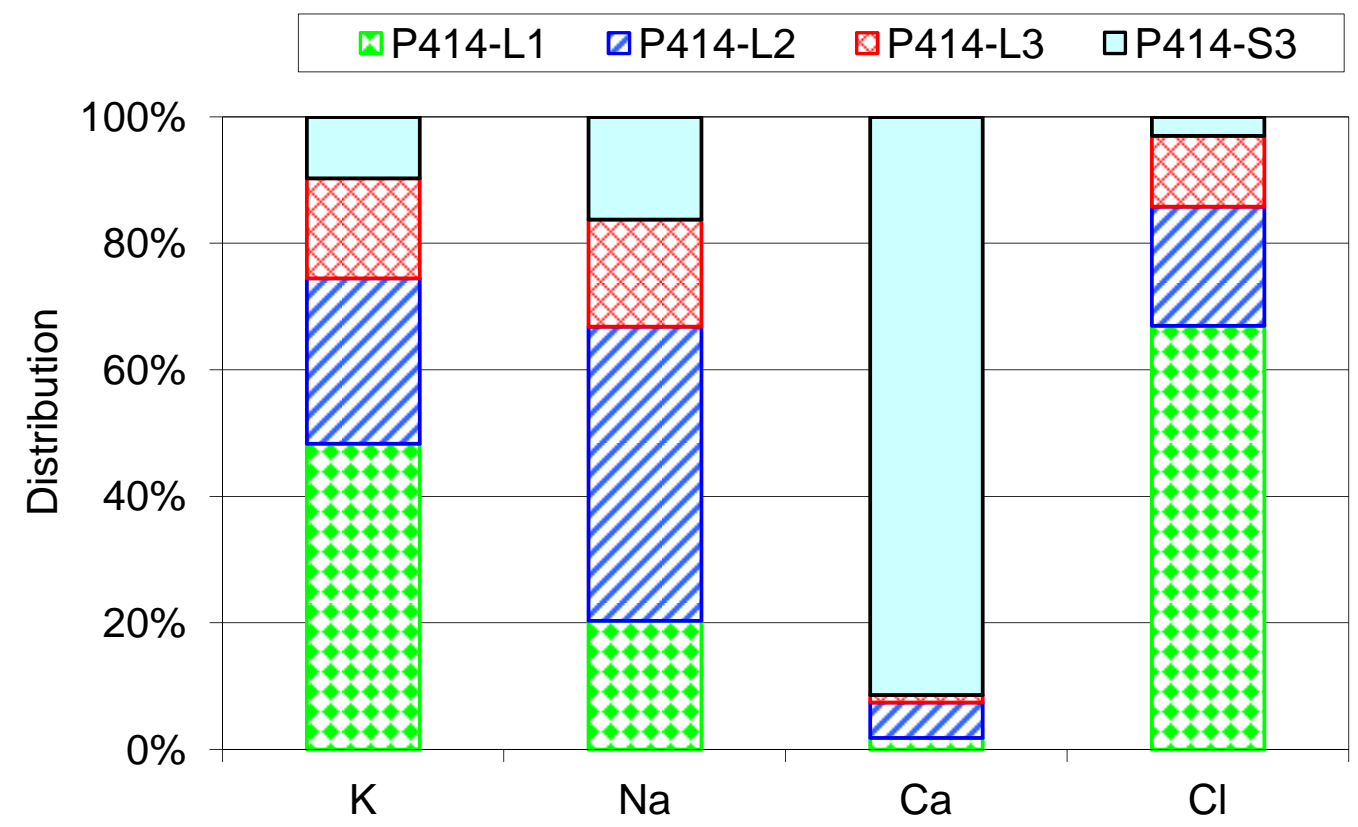

(d)

Fig 7 Elements fraction in the outputs of banagrass (Bana) at four effective exit cone pressures. (a: Bana-P0; b: Bana-P138; c: Bana-P276; d: Bana-P414) 


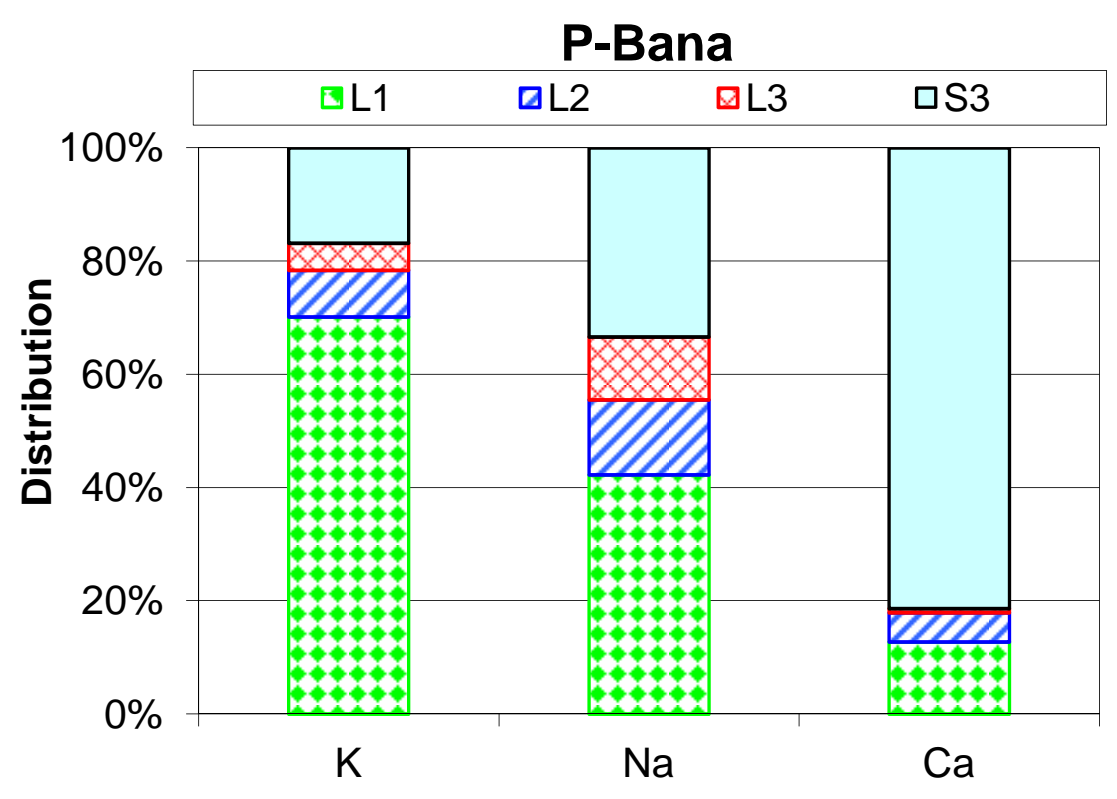

(a)

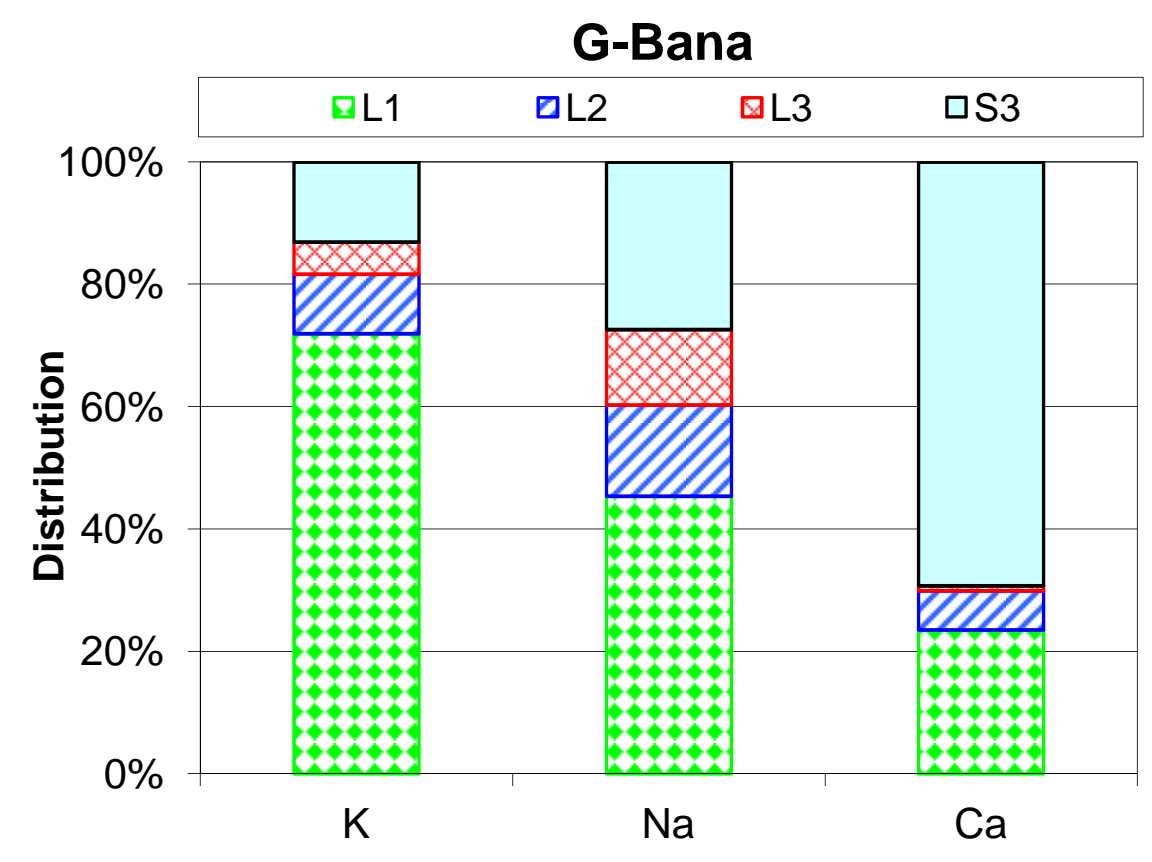

(b) 
OG03

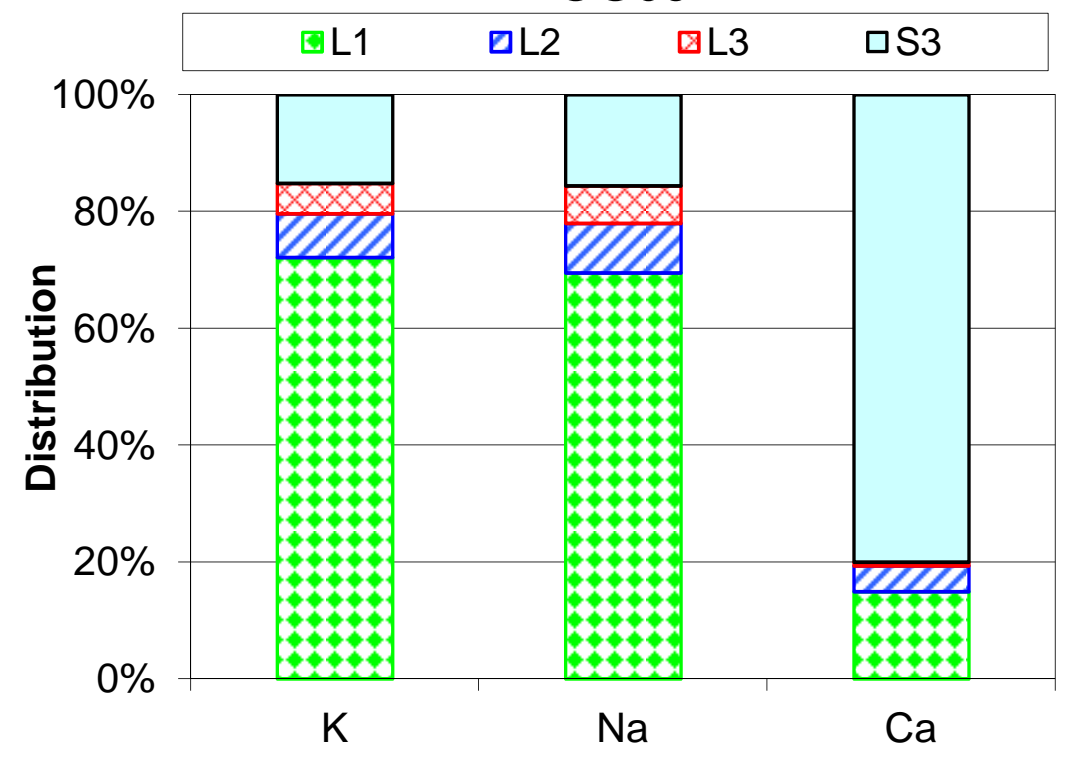

(c)

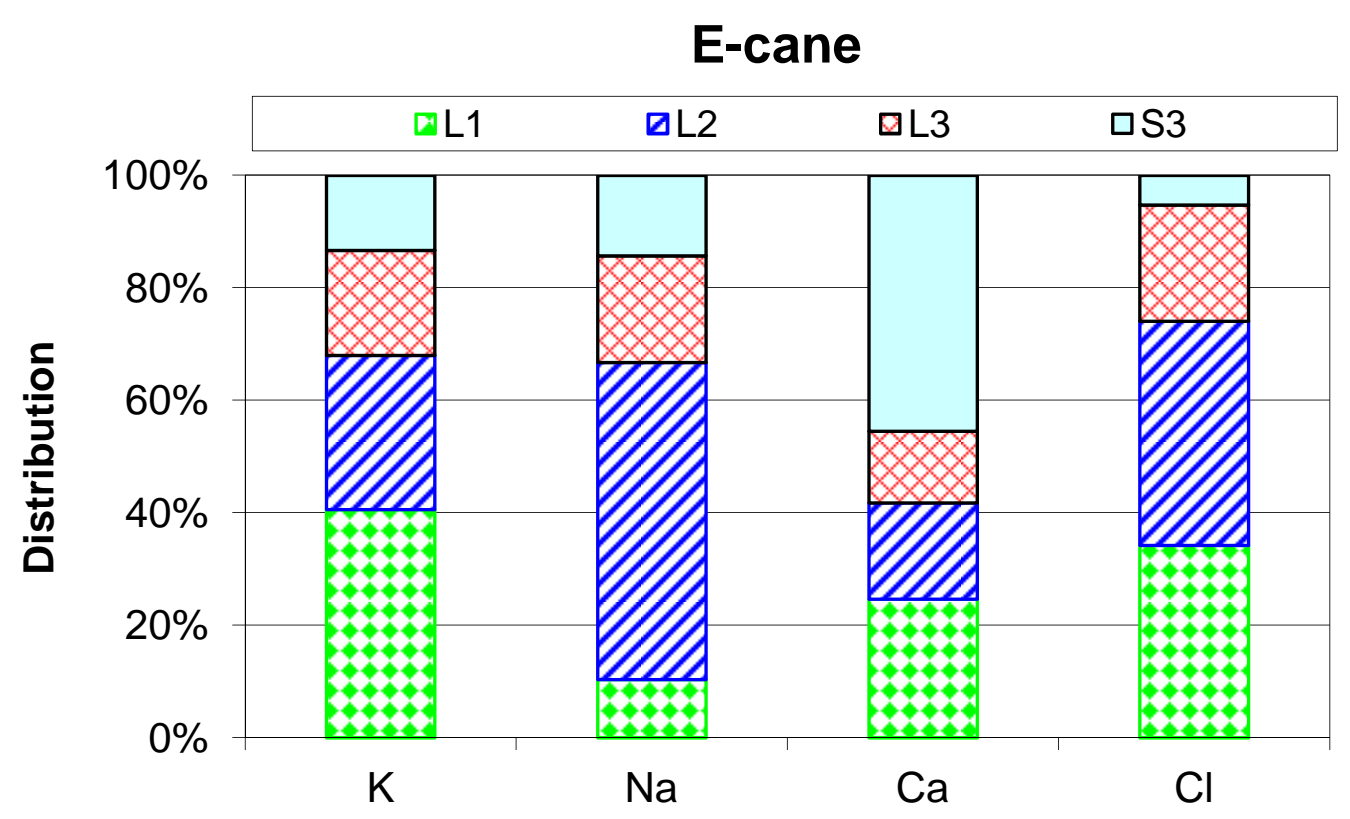

(d)

Fig 8 Elements fraction in the outputs from the screw press with exit cone effective pressure of $72 \mathrm{kPa}$ of (a) P-Bana, (b) G-Bana, (c) OG03, and (d) E-cane 


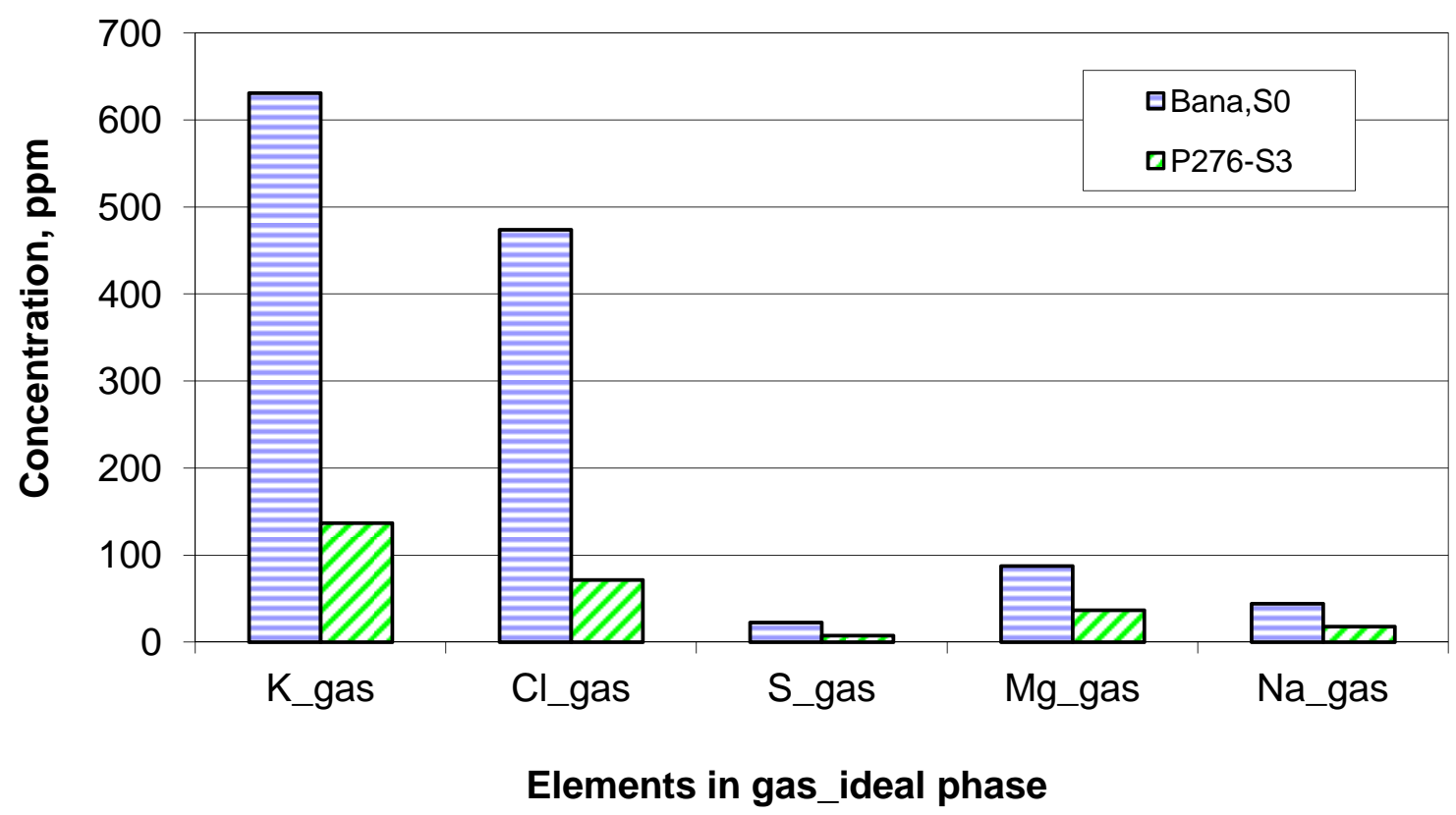

Fig. 9 Chemical equilibrium prediction of $\mathrm{K}, \mathrm{Cl}, \mathrm{S}, \mathrm{Mg}$, and $\mathrm{Na}$ in the product gas from steam-gasification of parent S0 banagrass and P276-S3 banagrass material (FactSage calculation conditions: $900^{\circ} \mathrm{C}$, steam/fuel $=2$ ) 